\title{
CRISIS AMBIENTAL: EL PENSAMIENTO RELACIONAL COMO ALTERNATIVA AL PENSAMIENTO DEPREDATORIO
}

\section{MARÍA ADELAIDA LÓPEZ ALZATE}

\author{
Universidad Santo Tomás \\ División de Filosofía y Teología \\ Facultad de Filosofía y Letras \\ Maestría en Filosofía Latinoamericana \\ Bogotá, Colombia \\ 2019
}




\section{CRISIS AMBIENTAL: EL PENSAMIENTO RELACIONAL COMO ALTERNATIVA AL PENSAMIENTO DEPREDATORIO}

\section{MARÍA ADELAIDA LÓPEZ ALZATE}

Tesis para optar por el Título de Magister en Filosofía Latinoamericana

Dirigido por: Dra. Claudia Patricia Giraldo Agudelo

Universidad Santo Tomás

División de Filosofía y Teología

Facultad de Filosofía y Letras

Maestría en Filosofía Latinoamericana

Bogotá, Colombia

2019 


\section{Dedicatoria}

Dedico este ejercicio investigativo a las comunidades Nativo Americanas que con su lucha y defensa de sus leyes de origen protegen la Tierra. 


\section{Agradecimientos}

Agradezco a mi padrastro Luis Enrique Camero Salas (q.e.p.d.), quien con su ejemplo y apoyo me sostuvo moralmente durante toda su existencia.

Agradecimiento con todo cariño por su apoyo a mi esposo, mi hija, mi hijo, mis hermanos y todo el resto de mi familia.

Agradezco muy especialmente a mis Profesores de la Maestría quienes liberaron mi pensamiento de "las cárceles del tiempo y la historia".

Por último, un especial agradecimiento a Claudia Patricia Giraldo Agudelo, Cesar Fredy Noel Ponguta Puerto y Nelson Fernando Roberto Alba, maestros que con su genuina orientación y paciencia hicieron posible este logro. 


\section{Resumen}

La presente investigación tuvo por objeto revisar y exponer visiones alternativas a la dicotomía entre cultura y naturaleza que sustenta un pensamiento depredatorio, que ha sido el causante de la crisis ambiental actual. En primer lugar, se tiene que las propuestas del filósofo suizo Josef Estermann basadas en el estudio del pensamiento amerindio, plantean un camino que muestran un tipo de relación cultura-naturaleza alterno al sistema de pensamiento capitalista de dominación de la naturaleza: extracción y acumulación. En sus revisiones de la filosofía andina, Estermann señala el posible origen de la dicotomía entre cultura naturaleza, y orienta la propuesta de la relacionalidad del todo (propia de la racionalidad andina) como una forma de unificación entre la cultura y la naturaleza.

De otro lado con este ejercicio exploratorio se quiere entonces, abordar otras formas de racionalidad que conduzcan a una resignificación de la naturaleza, de la relación ecosistema y cultura, y sus formas de transformación del entorno. En ese sentido se ponen en la mesa de discusión los estudios y planteamientos de antropólogos como Philippe Descola, quien propone diferentes rutas ontológicas para la comprensión de otras formas de ordenar la realidad y detenerse en el entendimiento del "Otro" en la investigación antropológica. Donde ese "otro" incluye a los

seres de la naturaleza no humanos. De igual manera el antropólogo Viveiros de Castro, quien a través del "perspectivismo amerindio" plantea minar los paradigmas eurocéntricos de la filosofía occidental, contribuyendo al igual que Descola a la revisión e introducción de la alteridad radical en los estudios de la realidad en el marco de las relaciones sociales en el mundo, actuando como traductores del pensamiento de otras civilizaciones y sabiendo que ellos tienen a sus espaldas todo el bagaje de la antropología social, intentan describir otro tipo de racionalidad que identifica pistas que ayudan a romper con la dicotomía entre cultura y naturaleza. 
Finalmente, se realiza un acercamiento al pueblo U’wa desde estudios etnográficos e históricos de la comunidad U’wa, realizados por estudiosos de la tradición de la antropología simbólica como son Ann Osborn o Ana María Falchetti y tomando como fuente a importantes líderes espirituales y activistas U’wa, como son Berito Cobaría y Daris Cristancho -escuchando sus propias voces y pensamientos- se señalan fundamentos del pensamiento U'wa y algunas posturas políticas, que darían cuenta de una racionalidad que contribuye a superar la dicotomía cultura-naturaleza.

Palabras claves: dicotomía naturaleza-cultura, crisis ambiental, comunidad U’wa, rutas ontológicas, perspectivismo amerindio, racionalidad andina, pensamiento relacional, pensamiento depredatorio, relacionalidad del todo. 


\section{Tabla de Contenido}

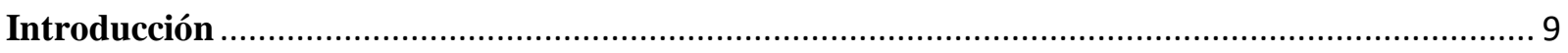

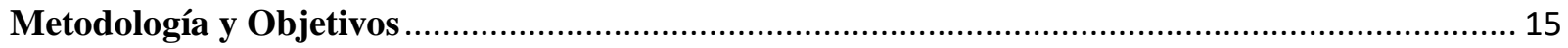

Capítulo I: El filósofo Josef Estermann y el Pensamiento Andino ….......................................... 17

1. Origen de la Dicotomía Cultura-Naturaleza: Josef Estermann...................................... 17

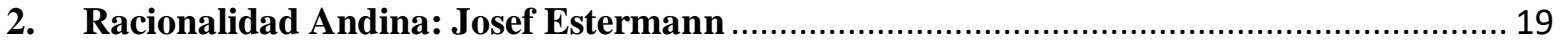

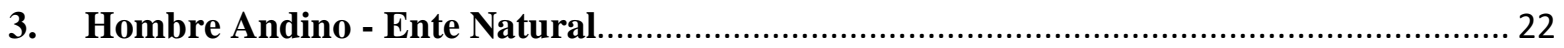

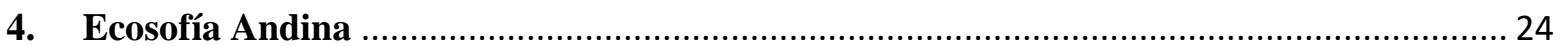

5. Axioma de la Filosofía Andina: Relacionalidad del Todo …............................................. 25

6. Principios Derivados del Principio de la Relacionalidad del Todo ................................. 28

Capítulo II: Mirada Antropológica al Problema de la Dicotomía Cultura-Naturaleza - Estudios

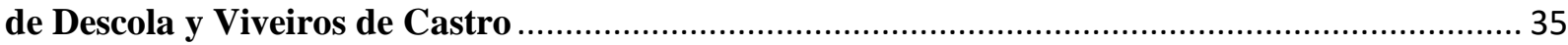

1. Las Cuatro Rutas Ontológicas de Philippe Descola ....................................................... 37

2. Vivieros de Castro y su Propuesta de Perspectivismo Amerindio como Alteridad Radical 52

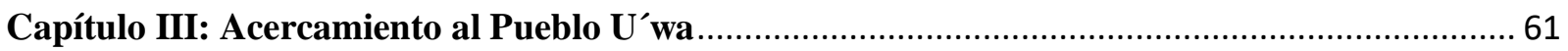

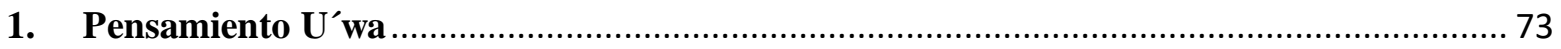

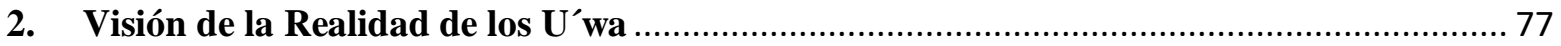

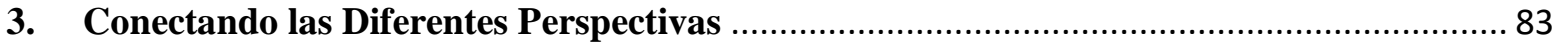

4. Propuesta alterna de los U'wa a la Dicotomía Cultura-Naturaleza ............................... 87

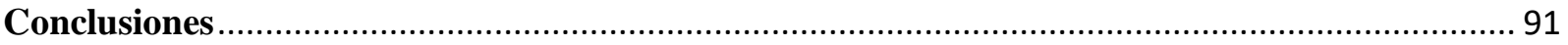

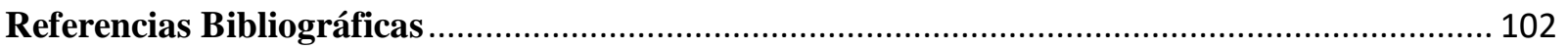




\section{Tabla de Ilustraciones}

Ilustración 1: Foto de la exposición la Fábrica de las imágenes ............................................................50

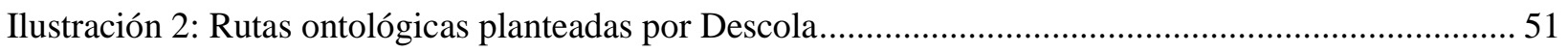

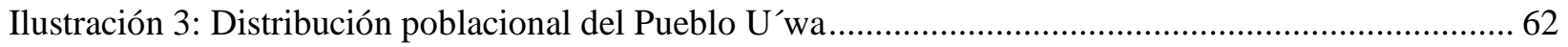

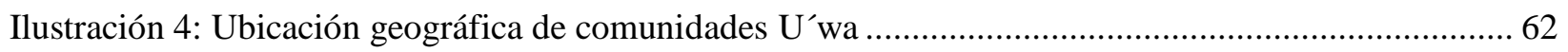

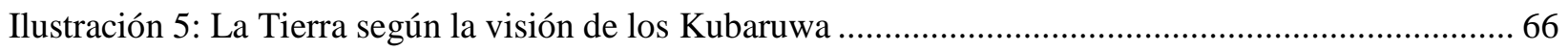

Ilustración 6: Desplazamiento de los U’wa a lo largo del año siguiendo el movimiento del Sol ............... 67

Ilustración 7: Ciclo anual de la celebración de los mitos cantados .......................................................... 71

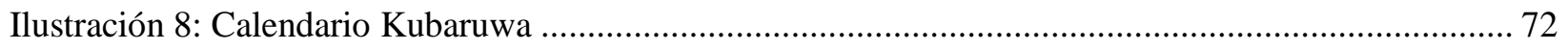




\section{Introducción}

El pretexto que sustenta el desarrollo del presente ejercicio reflexivo es la crisis ambiental, expresada en los altos grados de contaminación y extracción que sobrepasan los límites de la capacidad de la Tierra en su auto-depuración y su auto-regeneración, que conducen a un daño ambiental sin precedentes en la historia terrestre.

Desde finales del siglo XIX y hasta hoy, la problemática ambiental a nivel mundial aumenta alarmantemente, los diferentes tipos de contaminación son un reflejo de esta realidad. Dicha contaminación se encuentra en las fuentes de agua (causadas por vertimientos domésticos, industriales, radioactivos o petroleros), en el suelo (causada por exceso de agroquímicos, vertimientos industriales que contienen metales pesados y acumulación de residuos no degradables), en el aire (causados por emisiones del transporte de la industria y de energías contaminantes) y en los seres vivos (causada por el consumo de agua contaminada con mercurio o por los accidentes nucleares, como los de Chernóbil y Fukushima que alteran el metabolismo ocasionando daños neurológicos y cáncer). Dichas alteraciones en el planeta se observan en todas las latitudes, ningún país está exento, pues los diferentes ecosistemas se ven alterados en los ritmos de los ciclos biológicos y geológicos.

Las consecuencias del daño ambiental se manifiestan en el cambio climático mundial (inundaciones fuera de control, sequías severas, ciclones tropicales recurrentes de alta intensidad, descongelamiento de los glaciales, cambios en los tiempos de las estaciones o temporadas de lluvias), en la degradación de la capa de ozono, en el aumento de las enfermedades en humanos y animales y en la pérdida de biodiversidad. El planeta se altera, se sobrecalienta y se destruye, y de seguir con nuestro actual sistema de consumo, subsecuente acumulación de basuras de productos 
no degradables, sobreexplotación de los recursos naturales, vertimientos sin control y uso de energías dañinas, vamos por un camino que llevará al colapso ecológico.

La relación del ser humano (y de todo ser vivo) con la naturaleza, siempre ha tenido como objetivo el mantenimiento de la vida. La estrategia de sobrevivencia que ha establecido el hombre es la organización cultural, es a través de la cultura que el hombre transforma el medio ambiente usando instrumentos y técnicas en la agricultura, industria, pesca y comercio, con el fin de sobrevivir y perpetuarse; en dicha transformación siempre se generarán residuos (orgánicos o inorgánicos). El problema ambiental surge cuando en la relación cultura y naturaleza se producen alteraciones. De acuerdo a Foladori, (2005), se explica que cuando los elementos de la naturaleza son usados a una velocidad mayor en que ésta pueda regenerarlos y cuando la velocidad de la generación de los residuos también, es mayor a la capacidad de la naturaleza de absorberlos o degradarlos, se genera entonces, una oposición entre el ritmo de los ciclos biogeoquímicos de la naturaleza y los ritmos de la producción humana. En ese sentido, Foladori (2005) señala que los problemas ambientales pueden ser reducidos a dos grandes grupos: depredación y contaminación (Foladori, 2005, p. 11).

Estos dos grandes aspectos se exacerbaron con la revolución industrial del siglo XIX, orientada por una concepción capitalista de la producción, que como se sabe proporcionó a la humanidad mayor comodidad, mayor expectativa de vida y en consecuencia el aumento de la población humana, lo que ha conllevado a una mayor presión sobre la Tierra. Entonces, "la relación del ser humano con la naturaleza sufrió modificaciones significativas en su ritmo, amplitud, nivel, profundidad y grado de conciencia" (Foladori, 2005, p. 11). 
Se entiende por modificaciones en el ritmo o velocidad de la relación cultura-naturaleza, a que la producción capitalista tiene como organización social al "mercado", regido por la competencia lo que condiciona un aumento en el tiempo y en la cantidad de la producción (se deben producir siempre y cada vez más productos a partir de la materia prima). Esto tiene como consecuencia un uso cada vez mayor de los elementos naturales y la generación de más cantidad de residuos (Foladori, 2005, p. 12), de nuevo se tiene cada vez más depredación y más contaminación a una mayor velocidad.

En relación a las modificaciones de la relación cultura - naturaleza que tienen que ver con su amplitud, Foladori (2005) señala que por las necesidades de la competencia en la producción capitalista, ésta se expande o amplía a todo el globo terráqueo. Así, cuando ya se acaban los recursos (por ejemplo petroleo) en un área, se buscan otras zonas para continuar con la extracción. Esto conlleva a que la depredación y la contaminación se internacionalizan:

se profundiza la distancia entre el lugar donde los recursos fueron extraídos y el lugar donde los desechos son lanzados. Ese aumento de la distancia entre lugar de origen y de destino de los materiales complica aún más el metabolismo de reciclaje natural, ya que concentra materiales iguales fuera de los ecosistemas donde fueron generados (Foladori, 2005, p. 12).

La tercera modificación referida al nivel compara dos tipos de relaciones cultura-naturaleza: aquellas culturas no-industrializadas que usan la energía derivada de la fotosíntesis principalmente (la madera y los seres vivos) y las culturas industrializadas que basan su supervivencia en las energías fósiles como el carbón, el petróleo y la electricidad, las cuales "conllevan gran salto en las fuerzas productivas, con lo cual nuevos materiales y más distantes, tanto en extensión como en profundidad, fueron posibles de ser apropiados por el ser humano” (Foladori, 2005, p. 12). Las 
culturas industrializadas tienen un nivel de depredación y contaminación mayor que en aquellas no industrializadas.

En relación a la profundidad de la transformación de la naturaleza, se tiene que sumado a la revolución industrial del siglo XIX, se agregan otros elementos a los anteriores, en la revolución de los años setenta del siglo XX (micro-opto-electrónica, satelital y biotecnología): la creación de nuevos productos no biodegradables y de modificados seres vivos (Foladori, 2005, p. 12), profundizando y complejizando el problema ambiental.

Finalmente, la relación cultura-naturaleza se ha visto modificada en el grado de conciencia, puesto que la ideología hegemónica del capitalismo, no reflexiona sobre los efectos degradantes causados por este tipo producción. Solo después de las diferentes cumbres sobre medio ambiente (Estocolmo-1972, Rio de Janeiro-1992, Johannesburgo-2002, Cumbre Río+20-2012, New York2015, Madrid 2019), se han prendido las alarmas sobre los patrones de producción depredatorios y contaminantes en la actual relación cultura-naturaleza.

En estas reuniones mundiales se ha llegado a un imperativo común: el desarrollo sostenible. Esto ha tenido un aspecto positivo, en el sentido que, en dichas cumbres, se instala la preocupación mundial por el daño ambiental, pero en sentido negativo a la idea de desarrollo que se propagó en los años cincuenta del siglo XX, solo se le agregó el adjetivo sostenible, queriendo decir con ello que este desarrollo será permanente. Siendo el concepto de desarrollo sostenible aquel que propende por el uso de los recursos sin poner en riesgo las futuras generaciones en la satisfacción de las necesidades; este concepto encierra dos aristas de discusión: una que contempla a la sociedad humana como una unidad sin diferencias, precisamente estas diferencias son basadas en los diferentes comportamientos humanos con su ambiente que son "un resultado del tipo diferenciado 
de relaciones sociales de producción" (Foladori, 2005, p. 12). Y por el otro lado el solo hecho de agregar al concepto desarrollo, el adjetivo sostenible no discute para nada las relaciones de producción capitalistas. Es decir, a pesar de los esfuerzos mundiales en establecer lineamientos, mandatos o políticas, la problemática ambiental se mantiene, dado que no se atacan las formas de producción que ocasionan la depredación y la contaminación, y de otro lado la problemática es tan compleja que combina intereses económicos, sociales y políticos, lo cual "no es posible modificar uno de ellos sin que sus repercusiones alcancen a los demás" (Foladori, 2005, p. 15).

En ese sentido, la solución a la crisis ambiental tiene que ser compleja, pues les compete a los campos de conocimiento científico y tecnológico, los cuales aportan soluciones técnicas y actúan sobre las consecuencias físicas del daño ambiental. Le compete también a la reflexión filosófica que direcciona el análisis de las diferentes formas de racionalidad en las relaciones cultura-naturaleza, que producen ciertos comportamientos humanos y que son la expresión de sistemas de pensamiento. Entonces, en el presente trabajo se sostiene que la crisis ambiental se origina por un tipo de relación cultura-naturaleza establecida sobre una racionalidad económica y científica que en general ha negado a la naturaleza como fuente primera de riqueza, fuente de significaciones sociales y la raíz de la coevolución ecológico-cultural de la humanidad y por tanto ha generado una dicotomía entre la evolución cultural y la evolución natural. Por ello el problema del medio ambiente como se planteó anteriormente, es un problema de pensamiento, de un tipo de pensamiento que sustenta un comportamiento humano depredatorio, puesto que en la relación cultura-naturaleza se privilegia una relación de dominación por parte del ser humano hacia la naturaleza conllevando una fractura, esto es una dicotomía entre la cultura y la naturaleza.

En concordancia con lo expuesto anteriormente dicho y de acuerdo a Escobar (2012) la crisis social y ecológica que vive el mundo es en gran medida una crisis de los modelos de pensamiento 
que ha predominado en la modernidad, Escobar referencia a Boaventura de Sousa Santos en el sentido de que actualmente se afrontan "problemas modernos para los cuales no hay suficientes soluciones modernas" (Santos, B. 2002 citado en Escobar, 2012, p. 8). Por lo anterior Escobar invita a resolver los problemas del "desarrollo" a partir de varias matrices histórico-culturales y no solo de aquellas que parten de la modernidad. De allí, que es importante revisar diferentes concepciones en la relación cultura-naturaleza que están perpetuando la crisis ambiental o bien evitándola.

El objetivo de esta investigación es revisar y exponer visiones alternativas a este pensamiento dicotómico y a sus prácticas predatorias. En primer lugar, se tiene que las propuestas del filósofo suizo Josef Estermann basadas en el estudio de la filosofía amerindia, plantean un camino que muestran un tipo de relación cultura-naturaleza alterno al sistema de pensamiento capitalista de dominación de la naturaleza: extracción y acumulación. En sus revisiones de la filosofía andina, Estermann señala el posible origen de la dicotomía entre cultura naturaleza, y orienta la propuesta de la relacionalidad del todo (propia de la racionalidad andina) como una forma de unificación entre la cultura y la naturaleza.

De otro lado con este ejercicio exploratorio se quiere entonces, abordar otras formas de racionalidad que conduzcan a una resignificación de la naturaleza, de la relación ecosistema y cultura, y sus formas de transformación del entorno. En ese sentido se ponen en la mesa de discusión los estudios y planteamientos de antropólogos como Philippe Descola, quien propone diferentes rutas ontológicas para la comprensión de otras formas de ordenar la realidad y detenerse en el entendimiento del "Otro" en la investigación antropológica. Donde ese "otro" incluye a los seres de la naturaleza no humanos. De igual manera el antropólogo Viveiros de Castro, quien a través del "perspectivismo amerindio" plantea minar los paradigmas eurocéntricos de la filosofía 
occidental, contribuyendo al igual que Descola a la revisión e introducción de la alteridad radical en los estudios de la realidad en el marco de las relaciones sociales en el mundo, actuando como traductores del pensamiento de otras civilizaciones y sabiendo que ellos tienen a sus espaldas todo el bagaje de la antropología social, intentan describir otro tipo de racionalidad que identifica pistas que ayudan a romper con la dicotomía entre cultura y naturaleza.

Finalmente, se realiza un acercamiento al pueblo U’wa desde estudios etnográficos e históricos de la comunidad U’wa, realizados por estudiosos de la tradición de la antropología simbólica como son Ann Osborn o Ana María Falchetti y tomando como fuente a importantes líderes espirituales y activistas U’wa, como son Berito Cobaría y Daris Cristancho -escuchando sus propias voces y pensamientos- se señalan fundamentos del pensamiento U'wa y algunas posturas políticas, que darían cuenta de una racionalidad que contribuye a superar la dicotomía cultura-naturaleza.

\section{Metodología y Objetivos}

Dado que el presente ejercicio investigativo es de carácter documental a través del cual se pretende considerar alternativas de pensamiento ante la crisis ambiental, la metodología que se emplea para abordar dicha realidad, se centra en el paradigma cualitativo y humanista. Es así que la presente investigación se orienta por un análisis de tipo hermenéutico, es decir, interpretativo comprensivo. Según Cárcamo (2005), dicho análisis pone énfasis en la interpretación de los fenómenos particulares que acontecen en un tiempo y espacio definido y en el concepto de acción social, lo que implica elementos subjetivos internos en el actuar de los sujetos. El autor nos recuerda que, a diferencia del paradigma positivista, el sujeto ya no se encuentra condicionado por 
“elementos externos a él” sino que "su accionar estará dado en función del sentido que éste le otorga a sus experiencias" (Cárcamo, 2005, p. 205).

En resumen, el objetivo general de este ejercicio investigativo es reflexionar sobre las causas de la crisis ambiental que se encuentran asociadas a un pensamiento depredatorio y que subyacen a la dicotomía entre cultura y naturaleza e indagar por alternativas a esta crisis. Para lo anterior como objetivos específicos se encuentran poner en diálogo varias posturas que se presentan como alternativas al binomio cultura y naturaleza: las traducciones realizadas por el filósofo suizo Josef Estermann que entra en contacto con el pensamiento andino, las intermediaciones realizadas por antropólogos como Descola y Vivieros de Castro que buscan describir a partir del contacto con grupos indígenas, otros tipos de racionalidades y finalmente los U’was como comunidad indígena colombiana que con su forma de pensamiento y en su lucha política presentan una propuesta opuesta al pensamiento depredatorio. 


\section{Capítulo I: El filósofo Josef Estermann y el Pensamiento Andino}

Producto de una década de estudios y convivencia entre el filósofo suizo Josef Estermann y los runa (hombres quechuas) y jaqi (hombres aimaras) en Perú y Bolivia, el investigador realizó una profunda investigación sobre la riqueza filosófica de los pueblos andinos. En sus estudios defiende y rescata al pensamiento andino como autentica filosofía, su argumento se orienta a que la filosofía intercultural es una necesidad global para el nuevo milenio, dado que se pueden evitar conflictos y guerras entre etnias y culturas. En el presente estudio se hace uso de este recurso orientando dicha riqueza filosófica andina, como aporte a superar el pensamiento depredatorio.

A continuación, se indagará sobre el análisis que hace Estermann sobre el origen de la dicotomía cultura - naturaleza, luego se presentará cómo, a través de la filosofía andina se puede enunciar una racionalidad que no se basa en la oposición a la naturaleza y por tanto no concibe dicha dicotomía. Al desplegar los principios con los que opera dicha filosofía se pretende mostrar que contribuye a superar la crisis ambiental, mostrando al hombre andino como aquel que interviene el mundo de una manera que evita su desequilibrio.

\section{Origen de la Dicotomía Cultura-Naturaleza: Josef Estermann}

Según Estermann (2006) se podría rastrear el origen de la dicotomía naturaleza - cultura, en la tradición greco-occidental, al realizar Sócrates un "giro antropológico" y hasta epistemológico, en donde la physis (naturaleza) se convirtió en el 'objeto' de investigación por el ‘sujeto gnoseológico’ (2006, p. 187). Inclusive Platón establece la “inferioridad ontológica” de la physis con respecto al mundo de las ideas (eidé). Con Aristóteles la physis solo servía de trampolín para llegar a la meta physika, aunque se rescata la empireia en contraposición al mundo de las 
ideas de Platón. Continua el autor afirmando que para la tradición occidental la naturaleza es una realidad "desanimada" y bruta, una res extensa o una máquina como lo plantea Descartes (Estermann, 2006, p. 188).

Se tiene entonces que, por un lado, la raíz desmitificadora de la naturaleza se encuentra en la tradición greco latina, y por el otro en la tradición semita: cuando en el libro del Génesis se desacraliza el mundo, al afirmar que el creador es el dueño de los fenómenos físicos, dejando en bandeja de plata a la modernidad europea, el permiso para profanar y secularizar el universo físico. Se crea entonces la disyuntiva: cuando algo es Creador tiene carácter divino, pero cuando algo es creado es no-divino. Lo anterior se expresa mejor con el concepto de alma humana que entra en el cajón de lo espiritual y por el contrario la naturaleza física está en el cajón de lo no-espiritual (Estermann, 2006, p. 188).

Las consecuencias de estas lecturas son dramáticas para la naturaleza física y no-humana, unas por la influencia subterránea del platonismo y otras por la influencia definitiva de Descartes que inaugura la modernidad, al declarar la naturaleza no-humana como una simple res extensa (materia extensa) mecánica y cuantificable, con ello se logra la total secularización y desmitificación del mundo material y de los seres no-humanos. En consecuencia, lo ético se restringe a lo humano y teológico, y el campo de lo natural es el campo de lo amoral o neutralidad ética. En general, "la relación del espíritu occidental con la naturaleza es una relación instrumental y tecnomorfa" (Estermann, 2006, p. 189).

Las implicaciones más notorias de esta concepción occidental de la naturaleza se manifiestan en las relaciones de dominio, explotación, negación y menosprecio que se han mantenido y se siguen teniendo con la naturaleza, confiriéndole un valor netamente económico. Esta concepción de la naturaleza conduce a la creación de culturas desligadas de lo natural y que 
hoy en día se aprecian o expresan en el deterioro ecológico. Ni la crítica de Heidegger a la sociedad tecnomorfa y su insistencia en la tierra o la crítica de la razón instrumental de la Escuela de Fráncfort, han logrado marcar un cambio considerable en la concepción verdaderamente de fondo de la relación con el mundo natural y que conlleva a ese quiebre drástico entre cultura y naturaleza. Cada vez más como lo enuncia Estermann (2006) el hombre occidental se enajena de la naturaleza, la cosifica, la monetariza y la privatiza (Estermann, 2006, p. 190).

\section{Racionalidad Andina: Josef Estermann}

Opuesto a una concepción instrumental y tecnomorfa de la naturaleza, se encuentra la concepción andina de comunicación de la naturaleza a través del cultivo de la tierra y "a través de las formas ceremoniales de communio con las fuerzas vitales" (Estermann, 2006, p. 190). De acuerdo a esta forma de pensamiento; "El andino nunca interpuso instrumento alguno entre él y la naturaleza. Su relación con ésta es vital, ritual y casi mágica" (Estermann, 2006, p. 190). Cuando el autor se refiere a instrumento nos recuerda que el hombre occidental tiene como instrumento preferencial para relacionarse con la naturaleza (como reino de lo irracional) la lógica, el pensamiento discursivo y analítico: es un medio de acercamiento, pero a la vez de distanciamiento, pues la physis al ser acosada por el logos o bien escapa de su irracionalidad a-lógica, o bien se petrifica en una "naturaleza muerta" (tecnología) (Estermann, 2006, p. 191). Entonces, el instrumento del hombre andino no es preferencialmente la lógica, sino que usa la comunión a través de formas ceremoniales para relacionarse con su entorno.

La explicación anterior abre un espacio para la reflexión que ocupa este documento, la crisis ambiental como preocupación central, y que pretende escarbar cómo un tipo de pensamiento 
depredatorio causado por una dicotomía cultura-naturaleza conduce a profundizar dicha crisis. Se presentan entonces los estudios en filosofía andina, donde en el modo de pensar del hombre andino no se tiene una relación de oposición con la naturaleza. En su pensamiento la naturaleza no es un adversario que vencer. Al contrario de lo que la modernidad dicta sobre la naturaleza como un campo para explorar y dominar, existen otras concepciones, (sorprendentemente han sobrevivido) que no tienen una relación de oposición con la naturaleza, las cuales no han conocido la bifurcación cartesiana, y antes que concebir al hombre como ente racional y productor lo conciben como un ente natural, "conectado por un sinnúmero de nexos vitales con el conjunto de fenómenos naturales sean éstos de tipo astronómico, meteorológico, geológico, zoológico o botánico" (Estermann, 2006, p. 190). Dichas concepciones han sido preservadas principalmente por culturas indígenas, autóctonas, originarias y antiguas, que hoy en día conviven con las posturas occidentales.

La investigación realizada por el filósofo suizo Josef Estermann, en su cercanía con las formas de pensamiento de los indígenas de Perú y Bolivia, concreta lo que se denomina: Filosofía Andina. El investigador señala que dicha filosofía se rige bajo unos principios "lógicos" o expresado de una mejor manera: la lógica andina se basa en principios que se enuncian en una racionalidad sui generis, que tiene un sentido no-occidental. Dicha racionalidad no es algo que manifieste sólo teóricamente, sino que se expresa y se hace sentir en los diferentes ámbitos y regiones de la experiencia vivencial del hombre andino (Estermann, 2006, p. 151). El investigador suizo, concreta sus traducciones a través de lo que él expresa como una cierta "fenomenología andina" que intenta explicitar "un logos muy particular" de los múltiples fenómenos, no a la manera husserliana teniendo como objeto "la realidad en sí misma", sino como una interpretación de la misma, en una variedad de "expresiones vivenciales o interpretación colectiva de la realidad" 
(Estermann, 2006, p. 151). Entonces el autor es consciente de que su tarea es una interpretación "racional" de estos fenómenos, a la luz de los principios que el hombre andino vivencia y que de alguna forma el filósofo formaliza en el compendio denominado "filosofía andina" ofreciendo una comprensión intercultural.

Se puede entonces, hacer analogías o equivalencias para preguntarnos: ¿a qué equivale en la ‘filosofía andina' lo que llamamos la lógica?; la respuesta planteada por Estermann (2006), es que no hay un término en quechua o aimara análogo al término griego "lógica", pero insiste y justifica en declarar la existencia de una "lógica andina". Lo anterior básicamente está apoyado en que:

Si no tomamos el término "lógica" en un sentido técnico y greco-céntrico sino como un vocablo que indica la estructura básica de un cierto pensamiento. En el fondo se trata de la "racionalidad andina" pero en cuanto a sus principios básicos 'lógicos'. Cada pensamiento, cosmovisión, y hasta mito y fe tienen su 'lógica', una cierta forma intelectual regulativa (normatividad racional) que no tiene que ser necesariamente la forma occidental dianonética y bivalorada (Estermann, 2006, p. 25).

Adicionalmente, el autor plantea la existencia de una pluralidad de lógicas en la tradición filosófica: unas en sentido estricto (lógica formal, material, bivalorada, trivalorada, polivalorada, clásica, dialéctica, proposicional, modal, dóxica, deóntica) y otras en sentido amplio (lógicas de fe, científica, amorosa, política). La pluralidad de la lógica con respecto a su culturalidad es planteada por la filosofía intercultural, la cual posibilita la existencia de una pluralidad de racionalidades tales como la lógica occidental, lógica indica o lógica andina ${ }^{1}$ (Estermann, 2006, p. $123)$.

\footnotetext{
${ }^{1}$ Esta explicación la propone Estermann para mostrar que la lógica occidental carece de universalidad, y que para romper con esa pretensión es necesario llegar al campo de la interculturalidad, para que la lógica occidental no sea considerada como supra cultural, por ello se permite hablar por ejemplo de lógica andina.
} 
La lógica ha sido en el pensamiento occidental la piedra angular para declarar la validez universal de este pensamiento. Esta afirmación es pretensiosa para Estermann, dado que no se puede otorgar a dicho pensamiento un valor supra-cultural, súper-cultural o supra-temporal, sino todo lo contrario al igual que las diferentes teorías científicas, la racionalidad occidental esta “culturalmente determinada y tiene valor relativo" (Estermann, 2006, p. 124). Para el autor existen diferentes racionalidades, distintos paradigmas de “(re-)presentar la realidad". Sin embargo, no es ajeno en señalar que los términos "racionalidad" y "lógica" tiene su asiento en la filosofía grecooccidental, de allí que exista la dificultad, aún inclusive con el respaldo de la determinación cultural de la lógica, en hablar de "lógicas no occidentales".

Para el autor, la racionalidad andina tiene mayor conexión con la racionalidad oriental, dados los acontecimientos históricos en los cuales las comunidades orientales pasaron el estrecho de Bering hace más de 30.000 años para poblar el continente americano, por ello afirma que la "lógica andina" tiene más similitud con la "lógica china" (Estermann, 2006, p. 125).

Llamaremos entonces lógica andina al pensamiento basado en una racionalidad proveniente de la tradición andina, producto del devenir histórico cultural de los pueblos de los Andes de Perú y Bolivia que tiene su propia normatividad.

\section{Hombre Andino - Ente Natural}

En su convivencia con el hombre andino en Perú y Bolivia, Estermann es consciente de las dificultades hermenéuticas y epistemológicas para encontrar las fuentes de una filosofía andina, optó en un principio por un enfoque básico de la teología de la liberación, pero su primer momento se orientó hacia la experiencia y praxis vivida. En ese sentido el autor da un sentido básico a la filosofía andina como: "el conjunto de concepciones, modelos, ideas y categorías vividas y 
experimentadas por el runa/jaqi andino ${ }^{2}$, es decir, la experiencia concreta y colectiva del ser humano andino en su universo físico y simbólico" (Estermann, 2006, p. 74). En un sentido y derivado de la anterior definición del que el autor da testimonio, se encuentra que la filosofía andina además de ser praxo-lógica es una "reflexión sistemática y metódica de esa experiencia colectiva" (Estermann, 2006, p. 74)

Bajo esas concepciones filosóficas el ser humano andino interviene en el mundo de una forma no dominadora evitando su desequilibrio, respetando el ritmo orgánico que ocurre entre el nacimiento, crecimiento y reproducción. Afirma Estermann que para el andino el ser humano y los animales principalmente los domésticos, son compañeros que participan de una acción cultivadora en la que la pachamama es un sujeto, que tiene la capacidad de actuar y reaccionar. El ser humano “escucha" la relacionalidad que existe en la naturaleza: en el sentido de que al escucharla descubre la estructura simbólica en el misterio de la vida y en el ordenamiento cósmico y también, en el sentido de que debe obedecer dando respuesta adecuada con su comportamiento. Todo ello significa que el hombre andino escucha y obedece la estructura relacional con la que funciona la pachamama, no se ubica como un ente pasivo u anónimo, sino que no la cambia a su gusto, si lo hiciese traería como consecuencia desastres, o cambios en los patrones climáticos, sequías e inundaciones (Estermann, 2006, p. 193).

En otras palabras, su estrecha relación con los fenómenos naturales hace del hombre andino consciente de que si altera o cambia la naturaleza también se ve afectado a sí mismo. Estermann habla de una ética cósmica que rige a la "ecosofía andina", esto quiere decir que el hombre pide permiso, agradece y devuelve favores a la tierra antes de cualquier intervención, al igual que a los animales antes de consumirlos o de usarlos en el trabajo. De acuerdo a Estermann

\footnotetext{
${ }^{2}$ El ser humano (runa/jaqi) andino, ocupa un lugar en la red universal de relaciones; antes de ser "sujeto" o centro de gravitación cognoscitivo, es "parte" integral e integrada del cosmos (pacha) (Estermann, 2006: 191).
} 
el hombre andino antes que ser un "ente racional o productor" es un "ente natural" que tiene nexos con todos los fenómenos naturales

\section{Ecosofía Andina}

Según Estermann (2006) el concepto: “eco-Sofía” se construye para mostrar que eco - oikos en griego es casa (en quecha/aimara: wasi/uta) y sophia es sabiduría, Por ello en el mundo andino, dicha sabiduría es relacionalidad y donde ecosofía "significa la sabiduría andina del cosmos físico como una casa orgánicamente ordenada” (Estermann, 2006, p. 191).

Es interesante como Estermann realiza una traducción de ecosofía a "pachasofia" dado el significado de pacha como forma simbólica de casa, pacha que proviene de pachamama (madre tierra), en el pensamiento andino "la naturaleza es el todo de la realidad y no una entidad opuesta a otra (como culturalidad o espiritualidad)". Es significativo que en los idiomas quechua y aimara no exista un equivalente al concepto de naturaleza que se tiene en occidente, se denomina así: Tukuy binantin pacha (quechua), jakaña pacha (aymara), lo que equivale en español respectivamente: todo como pacha y territorio para vivir. Como se aprecia la naturaleza está asociada a toda la realidad del hombre andino, asociada a la pachamama la cual es un ser vivo orgánico. No hay cabida a las categorías occidentales dicótomas como vivo/no-vivo, orgánico/inorgánico, humano/no-humano, animado/innanimado. En la ecosofía andina el hombre es ante todo un agricultor y no un productor, es un socio un cuidador, co-creador de la casa común de todos los entes, no es distinto ni superior a los demás no-humanos, éstos merecen un trato justo de acuerdo a su posición en el orden cósmico (Estermann, 2006, p. 193).

En general, la ecosofía andina da cuenta de los principios "lógicos" que rigen la relacionalidad del todo, tales como la correspondencia, la complementariedad y la reciprocidad, 
que a continuación se exponen y que dan cuenta de una forma opuesta a un pensamiento depredatorio y que si se siguieran conducirían a mejorar la relación cultura - naturaleza y por tanto posiblemente contribuirían a superar la actual crisis ambiental: "para el runa/jaqi, la naturaleza no se puede 'conocer' lógicamente, sino sólo ‘vivir' orgánica y simbólicamente” (Estermann, 2006, p. 191).

\section{Axioma de la Filosofía Andina: Relacionalidad del Todo}

Estermann expresa la relacionalidad del todo como principio básico (axioma) de la racionalidad andina. El arjé de la racionalidad andina es el 'principio de la relacionalidad' o 'principio holístico'. Para el filósofo suizo este principio “afirma que todo está de una u otra

manera relacionado (vinculado, conectado) con todo.” (Estermann, 2006, p. 126). La entidad básica es la relación y no el "ente" sustancial. Para el autor o más bien para la lógica andina explicada por él, es la relación, su estructura primordial la que permite a los entes constituirse como 'entes'.

La lógica andina presenta la realidad como una concreción de la relacionalidad integral en donde los entes son 'concrecidos' en la medida que hacen parte de la interrelación. Es decir, un ente separado de la interrelación es un 'no ente'. Se es ente en la medida que haga parte de la interrelación. De acuerdo al autor la relacionalidad abarca una variedad de formas no lógicas, que no son solo lógicas o bien solo ontológicas:

Se trata de una relacionalidad sui generis, que implica una gran variedad de formas no-lógicas: Reciprocidad, complementariedad y correspondencia en los aspectos afectivos, ecológicos, éticos, estéticos y productivos. Las relaciones 'lógicas' (en sentido técnico) y gnoseológicas son más bien 
relaciones derivadas de las relaciones primordiales de convivencia cósmica (Estermann, 2006, p. 127).

El sentido negativo de la formulación del principio de la relacionalidad se expresa en que no puede haber ningún ente totalmente carente de relaciones, teniendo éstas últimas como relaciones trascendentes o relaciones inmanentes; de acuerdo a Estermann (2006) para el pensamiento andino no hay 'entes absolutos' en un sentido estricto. Para la filosofía andina hasta Dios no puede ser absolutamente trascendente, es decir un Dios no-relacionado. Carece de sentido para la lógica andina que exista un ente "en y por sí mismo, autárquicamente y de manera autosuficiente" (Estermann, 2006, p. 128). La declaratoria cartesiana que nos muestra un cogito ergo sum es un sinsentido pues ningún ente es arjé o principio de su propio ser.

Positivamente el principio de relacionalidad dice que "cada 'ente', acontecimiento, estado de conciencia, sentimiento, hecho y posibilidad se halla inmerso en múltiples relaciones con otros 'entes', acontecimientos, estados de conciencia, sentimientos, hechos y posibilidades." (Estermann, 2006, p. 128). Entonces positivamente el principio presenta la realidad como un todo holístico con seres y acontecimientos interrelacionados.

Estermann nos plantea una especie de contraste con las categorías lógicas de Occidente, procurando un debate que permita darle una mejor comprensión al modo de pensar andino. Para ello retoma las ideas occidentales sobre el relativismo, esencialismo, necesarismo, trascendencia e inmanencia a fin de encontrar alguna analogía.

Así nos ilustra que el sentido andino del principio de relacionalidad no es de tipo lógico (inferencia, implicación) tampoco es un contiguo queriendo decir que es algo de contacto directo 
o causal. La mayoría de los tipos relacionales son no causales (correspondencia, reciprocidad, polaridad y proporcionalidad). Para compararlo con alguna categoría occidental, se puede decir que el principio de la relacionalidad es esencial pero no necesario, así nos ilustra el autor de la siguiente manera:

aunque cada 'ente' en su 'ser' es esencialmente relacionado con todos los demás 'entes', esto no implica que los nexos relacionales concretos sean de naturaleza necesaria ... la estructura relacional andina tiene una cierta 'normatividad' ('esencialidad') que, sin embargo, permite una gran variedad de concretizaciones (Estermann, 2006, p. 130).

La realidad en sentido ontológico es relacional y su conocimiento es relativo. De acuerdo al autor "no puede haber un conocimiento 'absoluto' de algo 'relacional”" (Estermann 2006, p. 131). Se menciona en el texto que el principio de relacionalidad del todo no puede ser un supuesto culturalmente determinado. En la lógica andina el supuesto de que a través del logos se pueda representar de manera fidedigna la realidad es cuestionado. Es decir, "la filosofía andina rechaza tanto la inteligibilidad total de la 'realidad', como la 'intelectualidad' total del ser humano. No existe ningún paralelismo onto-gnoseo-lógico, porque la relacionalidad andina no es 'representativa' (Abbildtheorie), sino ‘celebrativo-simbólica’” (Estermann, 2006, p. 130).

De otro lado el principio de relacionalidad maneja de manera distinta la relación sujeto objeto, tal como se estructura en la filosofía occidental: "la relación congnoscitiva es una relación de 'conciliación' entre realidades bifurcadas." (Estermann, 2006, p. 135). Para el autor la mentalidad andina "no presupone una 'diástasis' entre un sujeto conocedor y un objeto conocido" (Estermann, 2006, p. 135). Para apreciar la complejidad o más bien la diferencia entre el ser y el conocer que se maneja en occidente, para la filosofía andina la realidad no-humana tiene características sapienciales: "para decirlo de una manera paradójica (en categorías occidentales): 
la 'realidad' nos conoce en ella, y nosotros conocemos a la 'realidad' en nosotros; tanto 'sujeto' como 'objeto' poseen intelectualidad, o, mejor dicho: sapiencialidad” (Estermann, 2006, p. 135).

En su afán de encontrar paralelismos que debatan la filosofía andina con posturas occidentales, se tiene por ejemplo la concepción de Dios la cual no se afirma con un carácter trascendente o absoluto, algo que este fuera de la realidad o más allá; pues para el hombre andino no hay nadie totalmente trascendente es decir separado ontológicamente, ni tampoco totalmente inmanente, pues para el runa/jaqi todo es relacional: todo es trascendental e inmanente a la vez (Estermann, 2006, p. 133).

El autor reflexiona que tal vez para el ser humano andino haya un poco de predominancia en la inmanencia en lo que tiene que ver con "las relaciones interpersonales, éticas, ecológicas, cósmicas y religiosas”... para el pensamiento andino “Dios es 'parte' de la 'realidad', más que una entidad más allá de ella; la otra persona es más 'parte' de la red relacional y de la naturaleza que realmente 'otro'. Lo común y conmensurable domina sobre la alteridad y la inconmensurabilidad." (Estermann, 2006, p. 133).

\section{Principios Derivados del Principio de la Relacionalidad del Todo}

De acuerdo al autor, el principio de relacionalidad del todo, es un axioma básico del pensamiento andino, del cual se derivan unos principios secundarios tales como el principio de correspondencia, que explica la manera como "los distintos aspectos, regiones o campos de la 'realidad' se corresponden de una manera armoniosa" (Estermann, 2006, p. 136). El autor 
diferencia esta correspondencia con categorías occidentales de connaturalidad, equivalencia, identidad o mediación. Aclara más adelante que se trata de una correlación, "una relación mutua y bidireccional entre dos 'campos' de la 'realidad"' (Estermann, 2006, p. 136). Estermann concluye de esta comparación que la correspondencia si bien es un ejercicio de correlación y que en la filosofía occidental se pueden encontrar huellas del principio de correspondencia, como, por ejemplo, en los pitagóricos cuando se refieren a la relación entre lo pequeño y lo grande, o entre la circulación sanguíneo y los movimientos celestes; en la filosofía andina los nexos relacionales son de tipo simbólico representativo y no causal o inferencial (Estermann, 2006, p. 138).

Un ejemplo de ello se presenta en la medicina homeopática en la que la enfermedad y la cura son correspondientes por estar compuestas de sustancias similares y por tanto al aplicar al enfermo la misma sustancia (en cantidades más pequeñas) de su correspondiente enfermedad, éste recobra la salud. Es importante distinguir la correspondencia de la causalidad la cual para lo andino es una de las tantas formas de relación, pero no la única.

La sugerencia que Estermann (2006) nos hace es que para la filosofía andina el principio de correspondencia va más allá de la relación causa y efecto, de la validez universal de la física newtoniana y geometría euclidiana, de la interpretación cuantitativa, causal y matemática de las relaciones:

En la filosofía andina, el principio de correspondencia incluye nexos relacionales de tipo cualitativo, simbólico, celebrativo, ritual y afectivo. No se trata, sin embargo, de una correlación análogoproporcional, tal como la postula la analogía entis medieval, sino de una correlación simbólica(re)presentativa. La filosofía latinoamericana de la vertiente 'inculturada' considera como rasgo fundamental de la sabiduría autóctona la 'mediación simbólica', y no la mediación conceptual (Scannone, Kusch, Cullen) (Estermann, 2006, p. 138). 
En resumen, el principio de correspondencia tiene una naturaleza simbólica, presentando la realidad desde diversas dimensiones que no necesariamente son causales, dicha naturaleza no es una representación sino una presentación con su propia lógica “de eficacia no-causal” (Estermann, 2006, p. 138). Son ejemplos del principio de la correspondencia aquella que existe entre el macro y el micro cosmos, entre "la 'realidad' cósmica de las esferas celestes (banaq o alax pacha) y la 'realidad' terrenal (kay o aka pacha), entre lo cósmico y humano, entre lo humano y no-humano, lo orgánico y lo inorgánico" (Estermann, 2006, p. 138).

Otro principio derivado del axioma: relacionalidad del todo es el principio de la complementariedad el cual explica que “ningún 'ente’ y ninguna acción existe 'monádicamente', sino siempre en co-existencia con su complemento específico. Este 'complemento' (con+plenus) es el elemento que recién 'hace pleno' o 'completo' al elemento correspondiente” (Estermann, 2009, p. 139). En este principio ningún ente es completo, sufre de una "deficiencia ontológica" es decir un no-ente un 'nada' (Estermann, 2009, p. 139).

La contraparte de un ente es su complemento imprescindible no su contrapuesto. El principio incluye a los opuestos complementarios. Por lo anterior este principio se correlaciona con el pensamiento oriental del Ying y el Yan: el círculo con sus partes complementarias y correlativas, cada una contiene a su contraparte u opuesto (Estermann, 2009, p. 141). El autor menciona ciertas diferencias: en la filosofía china la complementación se realiza a través de la meditación y la mística, mientras que para la filosofía andina se trata de una mediación celebrativa la complementación se da a través de un ritual celebrativo un proceso más pragmático de integración simbólica (Estermann, 2009, p. 142). 
Para el hombre andino "cielo y tierra, sol y luna, claro y oscuro, verdad y falsedad, día y noche, bien y mal, masculino y femenino no son contraposiciones excluyentes, sino complementos necesarios para la afirmación de una entidad 'superior' e integral.” (Estermann, 2009, p. 142).

A su vez el principio de correspondencia se expresa en un plano pragmático y ético como 'principio de reciprocidad': "a cada acto corresponde como contribución complementaria un acto recíproco" (Estermann, 2009, p. 145). Este principio es muy importante para la filosofía andina dado que "la ética no es un asunto limitado al ser humano y su actuar, sino que tiene dimensiones cósmicas" (Estermann, 2009, p. 145). En la racionalidad andina, la reciprocidad no sólo rige todo lo que ocurre entre las relaciones humanas, sino que abarca a todos los tipos de interrelaciones sean éstas entre el humano y la naturaleza o sea entre el humano y el ser divino, el actuar del hombre no está separado del cosmos o bien el cosmos no está separado del comportamiento humano, para el pensamiento occidental lo anterior es un absurdo, dado que para éste, los acontecimientos cósmicos y los humanos son independientes y por ello no hay un "deber ético" entre el ser humano y el cosmos. Por ello el autor reafirma la posibilidad de una "ética cósmica", la cual condensa todos los principios de la relacionalidad del todo, dado que la reciprocidad implica una relación que se constituye en un 'deber cósmico' más que en una interacción libre o voluntaria. Es decir, siempre los actos se condicionan unos con otros mutuamente en una inter-acción. Se trata de una compensación, de un equilibrio, se trata de justicia en el intercambio de bienes o sentimientos, entre actores y receptores.

Lo anterior se expresa en las relaciones comerciales aún vigentes basadas en el trueque. Dicha reciprocidad no solo se restringe al campo económico, es principalmente una categoría cósmica y una normatividad relacional que busca la 'justicia cósmica' (Estermann, 2006, p. 146). 
Por eso cuando las relaciones son unidireccionales se altera dicho equilibrio, para restaurarlo se requiere de "la reciprocidad de las acciones y la complementariedad de las y los actores/as" (Estermann, 2006, p. 147). En cierta forma para Estermann la justicia es sinónimo de equilibrio, en el análisis que realiza del principio de reciprocidad, pero el tipo de justicia del que habla es de “justicia cósmica": la reciprocidad tiene como base el "orden cósmico como un sistema armonioso y equilibrado de relaciones" (Estermann, 2006, p. 147).

Este principio opera en todos los planos de la vida andina: familiar, económico, ecológico, ético, de comportamiento y religioso; todo de conformidad con un orden cósmico de interrelación recíproca entre lo divino y lo humano (Estermann, 2006, p. 148).

En la racionalidad occidental, según Estermann, casi siempre las relaciones son unidireccionales: sujeto cognoscitivo-activo versus objeto cognoscitivo-pasivo. La naturaleza para occidente es un recurso que el hombre explota y trasforma, al cual no le devuelve o le compensa en nada. Para el andino esto no es compatible "con la 'justicia cósmica' expresada en el principio de reciprocidad" (Estermann, 2006, p. 149).

La forma de pensamiento andino, hace manifiestos los principios de correspondencia, complementariedad y reciprocidad, que, de acuerdo a la filosofía andina, si estos principios son observados se garantiza la continuidad de la vida, particularmente del orden cósmico:

Esta observancia es ante todo de carácter ceremonial y celebrativo, pero en el sentido de una simbología eficaz, y no de una simple "representación". El ser humano no "re-presenta" a la naturaleza, sino hace las veces de co-creador para mantener y llegar a la "con-creción" plena del orden cósmico (Estermann, 2006, p. 195). 
Concluye el autor que cuando no se siguen los principios anteriormente expuestos, las consecuencias se reflejan en la separación del hombre y el cosmos, lo que conduce a un antropocentrismo dominante, que ahonda la separación entre cultura y naturaleza, profundizando el antagonismo entre el homo faber y la naturaleza explotada. Si no se concibe una correspondencia entre la realidad cósmica y la realidad terrenal, o una correspondencia entre lo humano y lo nohumano, o bien si no existe complementariedad para lograr integralidad entre entidades o polos como son lo femenino y lo masculino o bien el cielo y la tierra, se conduce a una ruptura del conjunto de interrelaciones de la naturaleza, que es el todo de la realidad en el mundo andino. Si esto ocurre el hombre se desliga de la naturaleza. Se instala un modo de pensar que ubica o le da un carácter de inferioridad a la naturaleza no-humana con respecto al ser humano. La naturaleza entonces se convierte en un campo para vencer para dominar, así nunca la naturaleza podrá ser sujeto y por tanto no se puede concebir una relacionalidad del todo.

El principio de reciprocidad andino impide que las relaciones entre los fenómenos vitales y el ser humano o entre los elementos de la naturaleza y el ser humano sean jerárquicas, es decir, ninguna es superior o inferior a la otra, solo existen "correspondencias recíprocas entre entidades del mismo valor y peso" (Estermann, 2006, p. 160). Pero al parecer la filosofía occidental moderna ha logrado paulatinamente atomizar al ser humano y desnaturalizarlo. Desde Platón, Descartes y llegando a un punto culmen en el nihilismo de Nietzsche y el existencialismo absurdo del siglo veinte, el hombre se ha "descosmizado", se ha separado y ha roto la relacionalidad con el cosmos y la naturaleza. La filosofía andina discrepa con esta forma de separación, pues al negar la relacionalidad del todo que implica concebir una integralidad entre cultura-naturaleza se conduce inexorablemente a la destrucción ambiental. 
La reflexión que plantea Estermann a través de la racionalidad andina es importante, porque desarrolla una concepción de relación cultura-naturaleza que evita la crisis ambiental, puesto que está basada en un pensamiento que concibe a la naturaleza como el todo de la realidad, es decir para esta forma de racionalidad no habría dicotomía entre cultura y naturaleza, puesto que la cultura está inmersa en la naturaleza no es algo separado u opuesto. Es así que Estermann plantea una postura filosófica que denomina "ecosofía andina" donde el hombre es ante todo un agricultor y no un productor, es un socio un cuidador, co-creador de la casa común de todos los entes, no es distinto ni superior a los demás no-humanos, éstos merecen un trato justo de acuerdo a su posición en el orden cósmico (Estermann, 2006, p. 193). La cultura no se ubica por encima o por debajo de la naturaleza, a su vez la naturaleza no es un enemigo que vencer, sino un amigo que comprender.

Por lo anterior esta forma de pensamiento conlleva a un comportamiento que propicia el equilibrio en la existencia humana y no humana, que permite que las relaciones no sean únicamente de depredación y explotación, sino que se establecen mínimos acuerdos basados en los principios de relacionalidad del todo, correspondencia, complementariedad y reciprocidad, resolviendo el problema central de la crisis ambiental que es la depredación y la contaminación. Por tanto, la filosofía andina se introduce como parte del presente estudio dado que es un importante aporte para superar la crisis ambiental. 


\section{Capítulo II: Mirada Antropológica al Problema de la Dicotomía Cultura-Naturaleza - Estudios de Descola y Viveiros de Castro}

Para los fines de la presente investigación, que plantea el problema de la dicotomía culturanaturaleza como origen de la crisis ambiental, es importante la mirada antropológica por cuanto históricamente ha sido una preocupación que interesó a antropólogos sociales y culturales: encontrar los modos en que operan las relaciones entre lo humano y lo no humano (Tomé, 2009, p. 3). Adicionalmente, la relación entre naturaleza y cultura plantea la pregunta sobre la definición de humanidad, si solo lo natural (dotación genética humana) es suficiente para constituirse como humanidad, y a la vez la cultura se presenta como aquello que desvía o acerca a lo natural de su curso específico y, por lo mismo, como un factor de riesgo para la naturaleza misma (Tomé, 2009, p. 6).

De otro lado es una preocupación constante de la práctica antropológica evitar al máximo la “contaminación" de los presupuestos propios y que éstos predeterminen, restrinjan o bien se anticipen a la descripción, interpretación o explicación de los fenómenos a los que se enfrentan, es decir, se refiere a cómo afrontar el problema del etnocentrismo. Una apertura propiciada desde la antropología radicaliza el problema de "cómo ver mejor las cosas" y lo eleva a un problema mayor a nivel antropológico y es "de qué hay que ver en primer lugar” (Holbraad, 2014, p. 131). Entonces cuando el antropólogo mira a través de sus propios cristales no solo lo está haciendo con sus presupuestos sociales, políticos y culturales, sino ontológicos, y esto significa enfrentarse a los presupuestos sobre lo que las cosas son. El autor en mención resume esta preocupación en la siguiente pregunta: 
¿Cómo es que yo, antropólogo, neutralizo o pongo entre paréntesis mis suposiciones sobre lo que es el mundo y lo que hay en él para permitir que lo que está en mi etnografía y se presente en sí mismo como lo que es, y me otorgue la posibilidad de que lo que está allí sea diferente a lo que yo esperaba? (Holbraad, 2014, p. 131).

Visto de esta manera la preocupación tiene relevancia en la medida que dicho cristal permite o impide ver el problema ontológico (la visión de realidad que tiene una determinada cultura). Por ello la capacidad de los antropólogos en "hacer virar" sus propias presuposiciones para transformar su campo analítico: esto significa que en vez de usar la etnografía como el objeto de los conceptos, dicha apertura emplea a la etnografía como su fuente (Holbraad, 2014, p. 132).

Por ello para complementar la anterior perspectiva que plantea la filosofía andina basada en principios de relacionalidad del todo como postura que se opone a la división cultura-naturaleza y para encarar el hecho de que la división entre cultura y naturaleza se ha propagado como un único paradigma (González Varela, 2015, p. 43) Se quiere traer a la discusión los estudios antropológicos de Philippe Descola y Eduardo Viveiros de Castro que presentan diferentes racionalidades alternativas a la fractura entre cultura y naturaleza, a partir de estudios etnográficos. También, porque ellos han cuestionado sus propios preconceptos en su quehacer etnográfico, que impiden ver a los otras culturas y sus pensamientos en sus propios mundos, reduciéndolas a meras representaciones o visiones de mundo, estos autores se han permitido aperturas metodológicas que propenden por una comprensión de las racionalidades de culturas originarias, que contribuirian a superar la crisis ambiental.

Dichas aperturas provenientes de la antropología son importantes porque han contribuido a formular construcciones teóricas que señalan nuevas conceptualizaciones de la naturaleza diferentes a las planteadas en el naturalismo moderno. Han contemplado la posibilidad de mirar el 
pluralismo e ir más allá de dicho binomio cultura-naturaleza, pretendiendo trascender lo antropológico hacia "más allá de lo humano" (Ruiz Serna, 2016, p. 194). Indagan sobre los tipos de realidades que emergen cuando se desestabiliza la certeza de la dicotomía cultura-naturaleza, cuáles son sus propiedades, examinar acerca de lo que los mundos posibles nos dicen sobre las relaciones que se puedan establecer con los no-humanos o ciertos lugares. Preguntarse sobre el conocimiento mismo, dado que se pone en cuestión la concepción de lo que es real.

Los antropólogos Philippe Descola ${ }^{3}$ y Eduardo Vivieros de Castro ${ }^{4}$ comparten la crítica en relación a la divisíón entre naturaleza - cultura, como paradigma universal; comparten que dicha dicotomía ha sido fundamental en el desarrollo de la teoría antropológica desde que se inició y es parte de la ontología que caracteriza a occidente la cual, no es compartida por todos los grupos humanos (González Varela, 2015, p. 43). Viveiros y Descola también comparten la influencia de otras fuentes importantes las cuales se encuentran en Bruno Latour (2007), quien desde los años noventa evidenciaba cómo la herencia de la modernidad caracterizada por el humanismo que supuestamente saludaba el nacimiento del hombre, pero a su vez de manera asimétrica olvidaba el nacimiento de la "no humanidad" el de las cosas, animales, y mas aún de Dios, denunciando el tratamiento separado de estas: hombre, naturaleza y dios. Por eso para Latour, ésta constitución moderna ha marcado una forma particular de hacer antropología y de la cual el autor propone recomponer su simetría (Latour, 2007, p. 33).

\section{Las Cuatro Rutas Ontológicas de Philippe Descola}

\footnotetext{
${ }^{3}$ Philippe Descola nació en 1949 en Paris. Estudió filosofía y posteriormente etnología en la École Pratique des Hautes Études (EHESS) de Paris. Fue alumno de Claude Levi-Strauss quien le dirigió la tesis doctoral. Actualmente, además de ocupar la Cátedra de Antropología de la Naturaleza, dirige el Laboratorio de Antropología Social del EHESS. https://eixamestudis.wordpress.com/2015/11/23/lunes-sociologicos-philippe-descola/

${ }^{4}$ Eduardo Viveiros de Castro Río de Janeiro, Brasil, 1951, Etnólogo americanista, obtuvo su doctorado en Antropología en la Universidad Federal de Río de Janeiro (UFRJ) en 1984, y un posdoctorado en la Universidad de París X en 1989. Su teoría sobre el "perspectivismo amerindio" ocupa un lugar central en la reflexión etnológica contemporánea. http://www.katzeditores.com/fichaAutor.asp?IDA=237
} 
En su libro Más allá de la naturaleza y de la cultura el antropólogo francés Philippe Descola, discípulo de Lévi-Strauss, muestra cómo la organización espacial del Museo de Historia Natural de la ciudad de La Plata (Argentina) tiene un paralelismo con la construcción del conocimiento acerca de todo lo que existe en el mundo, es decir su comparación evidencia la manera separada en que el conocimiento está establecido, primero porque al igual que los diferentes estantes del Museo, el conocimiento está separado en grupos de dominios unos pertenecientes a las ciencias naturales y otros las ciencias de la cultura, así pues los pisos del museo muestran los estantes separados a los correspondientes para la naturaleza y otros estantes a los que pertenecen a las creaciones humanas sociales.

El autor señala cómo en esa "guerra de las ciencias", lo que se evidencia es -al igual que el museo de historia natural-, el edificio dualista donde en algunas se producen híbridos de naturaleza y cultura y en otras en la gestión interna del edificio dualista se da una imposibilidad de trazar una frontera consensual entre aquello que ataña a la naturaleza y lo que ataña a la cultura (Descola, 2011, p. 79). Hasta aquí la comparación entre la distribución de los objetos del museo y la forma en que el conocimiento se ha presentado principalmente para Occidente. Para Descola en el futuro la separación de los dos pisos será anticuada, dado los reclamos medioambientalistas, lo que implicaría un cambio de cosmología. El medio ambiente por donde se mire está antropizado en grados variados por muchas partes, por ello el autor denuncia que no es una entidad autónoma y pretenderlo es más una ficción filosófica (Descola, 2011, p. 80).

Descola presenta ejemplos claros de lo anteriormente dicho (dualismo), se presentan en los estudios y actividades de reproducción asistida, fecundación in-vitro, clonación de mamíferos, trasplantes, intervenciones en el genoma humano en procesos de embriogénesis, todo ello "vuelve 
menos neta que antes la separación del derecho entre la parte natural y la parte cultural del hombre" (Descola, 2011, p. 80). Estamos ante una situación ética y política y también ontológica que desmorona antiguas certezas: “el siglo XIX habrá enterrado a Dios; el siglo XX, dicen, ha borrado al hombre, el siglo XXI ¿hará desaparecer la naturaleza?” (Descola, 2011, p. 80).

Ante semejante panaroma lo que se está cuestionando es el concepto de naturaleza por el cual ha tenido por costumbre ser el objeto de dominación en las investigaciones, pues los procesos naturales siguen en este planeta independiente a pesar de su antropización, todo ello porque el concepto de naturaleza queda poroso por deslizamientos ontológicos que van rompiendo su anterior universalidad y unidad. Descola denuncia que es una constante la pregunta por las relaciones de continuidad y discontinuidad entre naturaleza y cultura en el desarrollo de la antropología (Descola, 2011, p. 83). En la expansión colonial se reunían datos de los pueblos dominados y surgían preguntas sobre la "manera extraña" en que dichos pueblos establecían relaciones con las plantas, los animales, o bien atribuían a una especie el lugar de "ancestro" teniéndolo como pariente cercano.

Es así como la etnología trataba de dar cuenta de estas demarcaciones y explicar los pensamientos "exóticos”. El contexto en el que surgió dicha disciplina contribuyó a zanjar más la división entre naturaleza y cultura pues en la segunda mitad del siglo XIX es donde más se compartimentaliza. Los métodos y programas científicos y la separación entre ciencias de la naturaleza y ciencias de la cultura, condenaron al medio ambiente a ser visto solamente como un marco externo a la vida social, y destinado a ser estudiado únicamente por los parámetros de las ciencias naturales. Es así, como la antropología se resigna a recibir del reparto, el estudio de la cultura limitando su horizonte, todo ello trajo como consecuencia que la antropología tendiara a 
privilegiar estudios orientados a indagar si "la naturaleza determina la cultura o bien es la cultura la que le da sentido a la naturaleza" (Descola, 2011, p. 84).

De acuerdo a lo anterior surgieron diferentes líneas de estudio o de abordajes dentro de la antropología, tales como las antropologías materialistas que consideraban el medio ambiente o la fisiología humana como motores de la vida social. Para la antropología marxista, la ecología cultural o la sociobiologi+a es el comportamiento humano o bien las instituciones o bien las representaciones colectivas, las cuales se podrían percibir como respuestas adaptativas a condiciones limitadas del ecosistema o a expresiones genéticas. Así, se dejó de lado el estudio en la forma como las sociedades "no modernas" conceptualizaban sus propias concepciones de cuerpo o medioambiente. Únicamente, se estudiaron para encontrar las convergencias o distanciamientos entre la plantilla señalada por la ciencia, es así que a todo se le añadía el prefijo etno: etnobotánica, etnozoología, etnofarmacología, etnobiología, etnomedicina, lo cual, le daba la impronta de "local y relativo", y en consecuencia se recortaban campos de práctica y conocimiento de estas sociedades, para así volverlos comparables con saberes naturalistas occidentales (Descola, 2011, p. 84).

De otro lado, Descola (2011) afirma que la antropología simbólica se ocupa de la oposición entre naturaleza y cultura para aclarar los mitos, rituales y las taxonomías, con el fin de realizar interpretaciones etnográficas, algunas cubiertas de prejuicios etnocéntricos, y bajo conceptos de naturaleza y cultura que referían "implicitamente a dominios ontológicos cubiertos del occidente modernos por estas nociones" (Descola, 2011, p. 85).

Descola reitera que en la modernidad existen pueblos que son indiferentes a las divisiones que occidente ha impuesto: a muchas entidades que nosotros llamamos naturales (animales, plantas, meteoros o montañas) ellos le han atribuido vida social y son tratadas como personas 
(2011, p. 85). La experiencia vivida en la Amazonía ecuatoriana en los años setenta le hizo entender, cómo para los Achuar un pueblo indígena, los seres están dotados de características humanas tales como poseer alma (Descola, 2002, p. 156). Existe según los Achuar una facultad en la que ubica ciertos no-humanos entre las personas: "en la medida que les asegura la conciencia reflexiva y la intencionalidad, que las hace capaces de experimentar emociones y les permite intercambiar mensajes con sus pares como con los miembros de otras especies, entre ellas los hombres" (Descola, 2002, p. 156). De lo anterior el autor en mención, plantea que "una naturaleza dotada con atributos de la humanidad ya no es evidentemente una naturaleza" (Descola, 2011, p. 85). Por lo anterior la invitación de Descola es realizar una antropología renovada:

cuyo objeto ya no serán las instituciones y las prácticas clasificadas según su grado de autonomía en relación con la naturaleza, sino las formas y propiedades de los distintos sistemas posibles de relación con el medioambiente humano y no humano que la etnología y la historia comenzaron a inventariar (Descola, 2011, p. 86)..

La naturaleza que plantea el autor basado en sus estudios de campo con los Achuar, tiene un contexto que implica como se mencionó que los no-humanos son tratados como personas, como compañeros sociales, estableciendo relaciones que están gobernadas por "esquemas sociales" (Descola P. , 2002, p. 157). Es decir, la naturaleza aquí no es "una instancia trascendente o un objeto para socializar, sino el sujeto de una relación social; prolongando de esta manera el mundo de la familia, la naturaleza es verdaderamente doméstica incluso en sus reductos más inaccesibles" (Descola, 2002, p. 157).

De lo anterior se puede pensar desde la antropología simbólica, que la humanización de los no-humanos (entre los Achuar, las plantas se conciben sobre relaciones de consanguinidad, y las 
relaciones con respecto a la caza de animales son asumidas sobre el modelo del parentesco por alianza) da mayor relevancia a la metáfora, pero no es así pues los Achuar entienden muy bien la diferencia entre lo literal y lo figurado (Descola P. , 2002, p. 158).

La idea de la discontinuidad entre cultura y naturaleza, para algunos antropólogos no es una opción poner en cuestión este dualismo, a pesar de que muchos pueblos en la modernidad no funcionan con estas concepciones dicotómicas, es decir, considerar a todo lo exterior al hombre y que no tiene atributos o están dotados de propiedades antropocéntricas como naturaleza. Se trata entonces de cosmologías opuestas pues en el pensamiento moderno, la oposición entre naturaleza y sociedad es una función rectora de su cosmología, mientras que cosmologías como las de los Achuar:

la mayoría de las plantas y de los animales están incluidos en una comunidad de personas que comparten todas o algunas de las facultades, comportamientos y códigos morales ordinariamente atribuidos a los hombres, no responde, de ninguna manera, a los criterios de un tipo de oposición... (Descola, 2002, p. 159).

Occidente ha tenido en su base cosmológica la oposición entre naturaleza y cultura, donde la naturaleza tiene sentido en la medida que es transformada en la cultura, lo que ha ocurrido es que principalmente en occidente dicha transformación ha sido la causante de la actual crisis ambiental, por ello Descola afirma que:

estoy convencido que se rompió el equilibrio mediante la utilización desenfrenada del medio ambiente. Se suele decir que la forma en que se trata a los humanos es un indicador de la forma en que se mira la naturaleza, que nuestras instituciones son el reflejo de la idea que uno tiene de ella. Creo que lo que hacemos con la naturaleza es también un buen indicador de nuestra forma de tratar a los seres humanos y que una actitud depredadora de los recursos naturales tiene como corolario una 
utilización inhumana de los hombres. No fue una casualidad si la segunda expansión colonial se produjo en plena revolución industrial: las poblaciones colonizadas, relegadas al rango de recurso natural, tenían derecho al mismo trato que el carbón de las minas (Descola citado en Corradini, 2006, p. 1).

En atención a lo anterior la pregunta que surge para darle peso a la idea que preocupa en este ejercicio reflexivo es ¿cómo incorporar a lo humano lo no-humano para que le permita la coexistencia en un medio ambiente sin destruirlo o bien minimizando el daño?; por eso el autor plantea la pregunta: “¿Cómo concebir la multiplicidad de relaciones que los humanos mantienen con los no-humanos?” (Descola, 2002, p. 159). Para dar respuesta a ello acude a Leví-Strauss para mostrar rutas ontológicas.

A continuación, Descola (2011) plantea el concepto de identificación, el cual define como el mecanismo para establecer diferencias y semejanzas entre las personas y las no humanas mediante el establecimiento de analogías y diferencias de apariencia, de comportamiento y de propiedad entre el pensamiento de lo que es el ser humano y el pensamiento de lo que son los demas tanto otros humanos como no-humanos. Esta identificación desempeña un papel importante en las maneras de aprehender y distribuir las continuidades y discontinuidades entre lo humano y no-humano. Para Descola, los criterios que entran en juego en la identificación son la interioridad y la materialidad. Dicha dualidad no es una proyección etnocéntrica propia de occidente de la distinción entre el alma y el cuerpo, sino que permite una multitud de conexiones e interacciones. Estas interioridades y materialidades pueden presentar semejanzas o diferencias. Es así que el autor presenta un nuevo procedimiento, definiendo cuatro grandes tipos de ontologías, lo que permitiría para Descola salir de la dicotomía, incluso metodológica entre la naturaleza y la cultura. 
La importancia de la identificación para la distribución de las discontinuidades y continuidades en el medio ambiente, usando dos criterios discriminantes: la interioridad y la materialidad, como se dijo, es que estos criterios son omnipresente en todos los pueblos, más que la distinción entre alma y cuerpo, estos dos criterios parecen cumplir una función importante en la identificación a través de "la atribución al otro de una interioridad análoga a la mía y la atribución al otro de una materialidad análoga a la mía" (Descola, 2011, p. 86), o dicho de otra manera en términos de Mauss (1974) "el hombre se identifica con las cosas e identifica a las cosas consigo mismo teniendo a la vez el sentido de las diferencias y de las semejanzas que establece" (Mauss 1974 , p. 130, citado en Descola, 2011, p. 86)

Las diferentes combinaciones que permiten estos dos criterios (interioridad y materialidad) conducen a grandes tipos de ontologías, a lo que el discipulo de Lévi-Strauss define como "sistemas de propiedades que sirven de anclaje de las formas cosmológicas, de los modelos de lazo social y de las teorías de la alteridad" (Descola, 2011, p. 87). No obstante dichas modalidades de la identificación no agotan las diversas formas de estructurar la experiencia individual y colectiva. El antropólogo señala que los principios que rigen la relación, figuración o la temporalidad participan de las muchas soluciones que los humanos le dan con el fin de "objetivarse en el mundo" y así hacer inteligibles las relaciones que los humanos establecen entre sí y con los no-humanos.

De acuerdo con Sánchez-Criado (2005) las cuatro rutas ontologías que define Descola son: a) totemismo (basado en la continuidad de 'materialidades' e 'interioridades' entre humanos y no humanos); 
b) animismo (basado en una continuidad entre humanos y no humanos en lo que se refiere a la 'interioridad', mientras que lo que los diferencia es su 'materialidad');

c) analogismo (que postula una discontinuidad básica entre humanos y no humanos tanto en su 'materialidad' como en su 'interioridad'); y

d) naturalismo (que nos une a humanos y no humanos por una continuidad 'material' y nos separa por la 'aptitud cultural' o por la diferente capacidad de interioridad, siendo esta última la más característica de nuestra tradición) (Sánchez-Criado, 2005, p. 3)

De acuerdo con el antropólogo en el totemismo los humanos y no-humanos comparten propiedades físicas y morales que los clasifican juntos según diferentes categorías como son el color de la piel, la morfología o cualidades como ser rápido; por ejemplo, un hombre podría decir que él y un canguro son iguales porque tienen un principio común como la vivacidad (Corradini, 2006, p. 1). Así en numerosas tribus:

el tótem principal de un grupo una especie natural, un objeto, un elemento de relieve, una sustancia o una parte del cuerpo humano $-\mathrm{y}$ todos los seres, humanos y no humanos, que le son afines son conocidos por compartir propiedades fisiológicas, físicas y psicológicas en virtud de un origen común y localizado en el espacio (Descola, 2011, p. 89)

El totemismo permite a las comunidades conceptualizar sobre su estructura social. Así las plantas o los animales les sirven como soporte, como un método de pensamiento, y les ofrece una representación icónica simple (Descola, 2011, p. 88). Principalmente el totemismo se encuentra en los aborígenes de Australia (Silla, 2016). Para dichos grupos la naturaleza es motivo de veneración y unión y se manifiesta materialmente mediante los tótems, que están vinculados con algún elemento o algún aspecto de la naturaleza que puede ser una casa o un individuo, al que el 
grupo humano rinde culto. Los tótems se han clasificado en aquellos que son de culto individual, los de índole local, pasando por los vinculados con el sexo o con la familia. Este orden fundamentado en tótems favoreció el desarrollo de una organización social basada en clanes, que a su vez se dividieron en casas, con lo cual se difundió una gran variedad de relatos propios de los pueblos originarios de Australia. (Barceló, 2012, p. 2)

La segunda ruta ontológica que resucita Descola es el animismo, y se dice que la "resucita" puesto que la mayoría de los antropólogos la creían y desearían muerta: “convertido en un enunciado de creencia falsa, infantil e irracional, el concepto de animismo permaneció desterrado de la antropología durante prácticamente un siglo” (González, 2016, p. 106). Y ¿por qué se creía falsa?: el animismo le otorga intencionalidad, subjetividad, personeidad a seres o bien entidades no-humanas; para Descola el animismo es "simétricamente inverso" al totemismo dado que éste último le otorga orden al conjunto social a través de las discontinuidades observables en el mundo natural, mientras que el primero le confiere "disposiciones humanas y atributos sociales a los seres naturales con la intención de regular las relaciones con ellos" (González, 2016, p. 107). Con esta recuperación teórica del animismo Descola puede defender que en el mundo amazónico (y muy probablemente andino también), el problema de comprensión no es exclusivamente semántico, sino que se trata de que realmente los grupos indígenas dotan con características sociales a los seres que la tradición occidental los encuadra en la naturaleza apartada como objetos (plantas, animales). Esto desentona con los referentes con los que la antropología se ha construído y son aquellos en los que la naturaleza y cultura estan escindidos en una relación de sujeto - objeto donde a la naturaleza le corresponde la parte del objeto, y sobre el que se ha construido ruta ontológica del naturalismo moderno como se verá más adelante. 
En esta ruta ontológica los sistemas anímicos humanos y no-humanos poseen una interioridad de la misma naturaleza, son personas dotadas de un alma lo que les permite comunicarse con los humanos, por tanto llevan una vida social idéntica a la de los hombres, es decir, comparten una humanidad como una condición o referencia compartida. Los humanos y nohumanos pueden tener materialidades externas diferentes, en tanto sus interioridades son idénticas (Descola, 2011, p. 90). Los cuerpos son simples ropajes que tienen especificidades de acuerdo a sus particulares fisiologías, pero tienen una cultura compartida, es decir, "unos como los otros tienen entonces una visión integralmente cultural de su medioambiente en razón de una interioridad calcada de la de los humanos, pero el mundo que aprehenden se les aparece diferente en razón de sus respectivas materialidades corporales." (Descola, 2011, p. 90).

La tercera ruta ontológica que propone Descola, es el analogismo, es descrito como un intermedio entre el totemismo australiano y el animismo. Sustenta sus explicaciones en que algunas características, o bien propiedades o eventos de elementos o entidades del mundo, ejercen influencia a distancia sobre el destino o influyen en el comportamiento de los humanos. Ejemplos de este tipo de ontología coexiste actualmente y otros están en desuso, tales como correlaciones entre el microcosmos y el macrocosmos lo que funda la geomancia y la adivinación china (Descola, 2011, p. 91). También, existen ejemplos en Africa donde se comprende que ciertos desordenes sociales pueden acarrear catástrofes climáticas. Otra expresión de analogismo se encuentra en la teoría médica acerca de las semejanzas que ciertas materias, sustancias y objetos naturales poseen con los síntomas o las partes del cuerpo humano, con el fin de determinar la etiología o la terapéutica de las enfermedades. El analogismo no requiere ninguna relación directa de persona a persona entre humanos y no humanos, pero implica que existe entre ellos una similitud de efectos 
a través de una acción lejana o una resonancia involuntaria (Descola, 2011, p. 92). No esta fundado en la homologia de las interioridades o en la diferencia de las materialidades asi como lo hace el animismo o bien en una compartimentalización de las interiorides y materialidades como el totemismo australiano. Se puede hablar que para el analogismo los humanos y no-humanos pertenecemos a una misma colectividad en el mundo y son las analogías perceptibles las que propician una organización interna y sus propiedades de dicha colectividad. Para darle una terminología antropológica Descola, resume la visión analogista como un cosmocentrismo, el totemismo lo describe como cosmomorfismo y el animismo como antropocentrismo al igual que la postura ontológica del naturalismo como se verá en seguida.

La cuarta ruta que describe Descola, es el naturalismo moderno, la cual es la ontología que ha predominado en el pensamiento principalmente occidental. El naturalismo considera la existencia de una naturaleza única y una multiplicidad de culturas y concibe que hay diferentes interioridades y un continuo evolutivo en las materialidades. La distinción entre humanos y nohumanos es claramente el alma, la consciencia y la subjetividad. Los humanos se encuentran distribuidos en colectividades que se diferencian en sus diferentes culturas, pero por su parte los no-humanos se encuentran en la distribución de aquellos que carecen de alma y por tanto de subjetividad, lenguaje o interioridad o sea son objetos. Dicha discriminación ontológica le da permiso de usar y ver a la naturaleza como un objeto bien sea de conocimiento, de estudio o de explotación. Esta ontología ha pretendido y ha tenido el poder persuasivo de erigirse como:

El árbitro universal capaz de producir la representación más detallada, y quizá la única valida, de la realidad (naturaleza). El poder persuasivo de la ontología moderna llega entonces al punto de erigirse no sólo como el rasero para definir y legitimar lo que es susceptible de ser legible en el mundo 
contemporáneo, sino de proyectarse como la única ontología existente, cuando tan sólo es una entre varias más, aunque sin duda la más poderosa... (Ruiz Serna, 2016, p. 200-201).

Lo que caracteriza a esta visión, en definitiva, es que piensa que hay una naturaleza única sobre la que se inscriben las diferentes representaciones culturales (González, 2016, p. 107). Esta postura acepta entonces el multiculturalismo y escinde una brecha mayor entre naturaleza y cultura.

En resumen, para Descola la ontología es el "sistema de las propiedades que los seres humanos atribuyen a los seres y que interviene en la determinación del tipo de relaciones posibles entre entidades humanas y no-humanas" (Ruiz Serna, 2016, p. 195). En resumen, según Mitrovic (2013) Descola propone un proyecto entero de una antropología de la naturaleza, sobre el que reposa el carácter relacional de la mente humana donde varían los atributos de interioridad o materialidad, teniendo diferentes combinaciones dadas asi: + y - indican atribución de igualdad (+) o de diferencia (-):

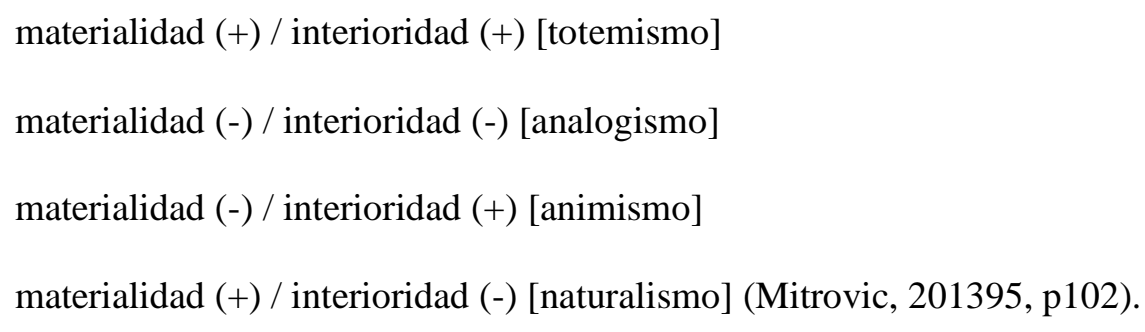

En las siguientes imágenes se muestran las diferentes rutas ontológicas anteriormente explicadas. 


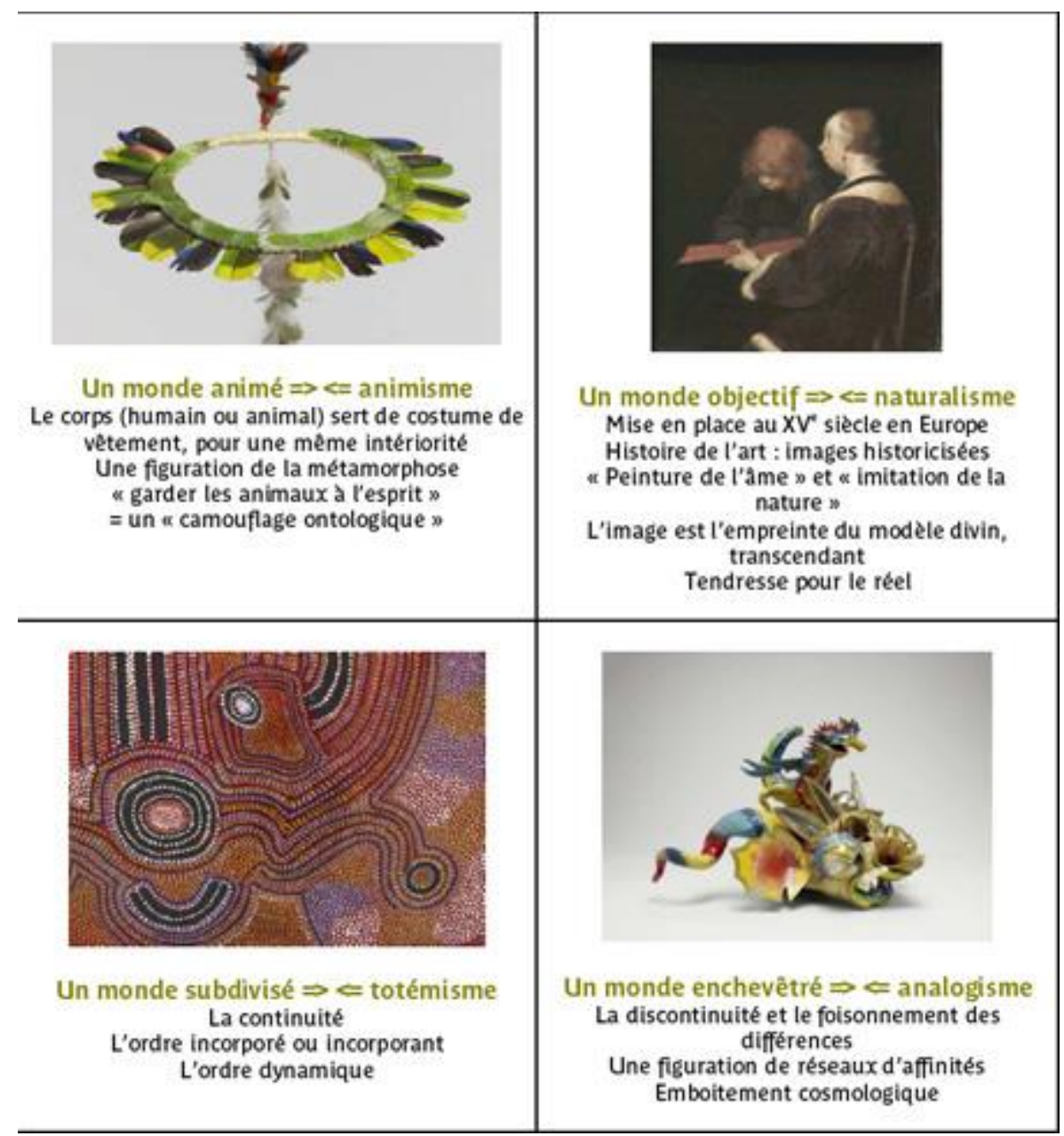

Ilustración 1: Foto de la exposición la Fábrica de las imágenes

"La fabrique des images” Exposición Musée du Quai Branly du 16 février 2010 au 17 juillet 2011. Realizada por P. Descola con 160 representaciones de las cuatro rutas ontológicas.

Fuente: http://detoursdesmondes.typepad.com/dtours_des_mondes/2010/01/la-fabrique-des-imagesmus\%C3\%A9e-du-quai-branly-descola.html. 


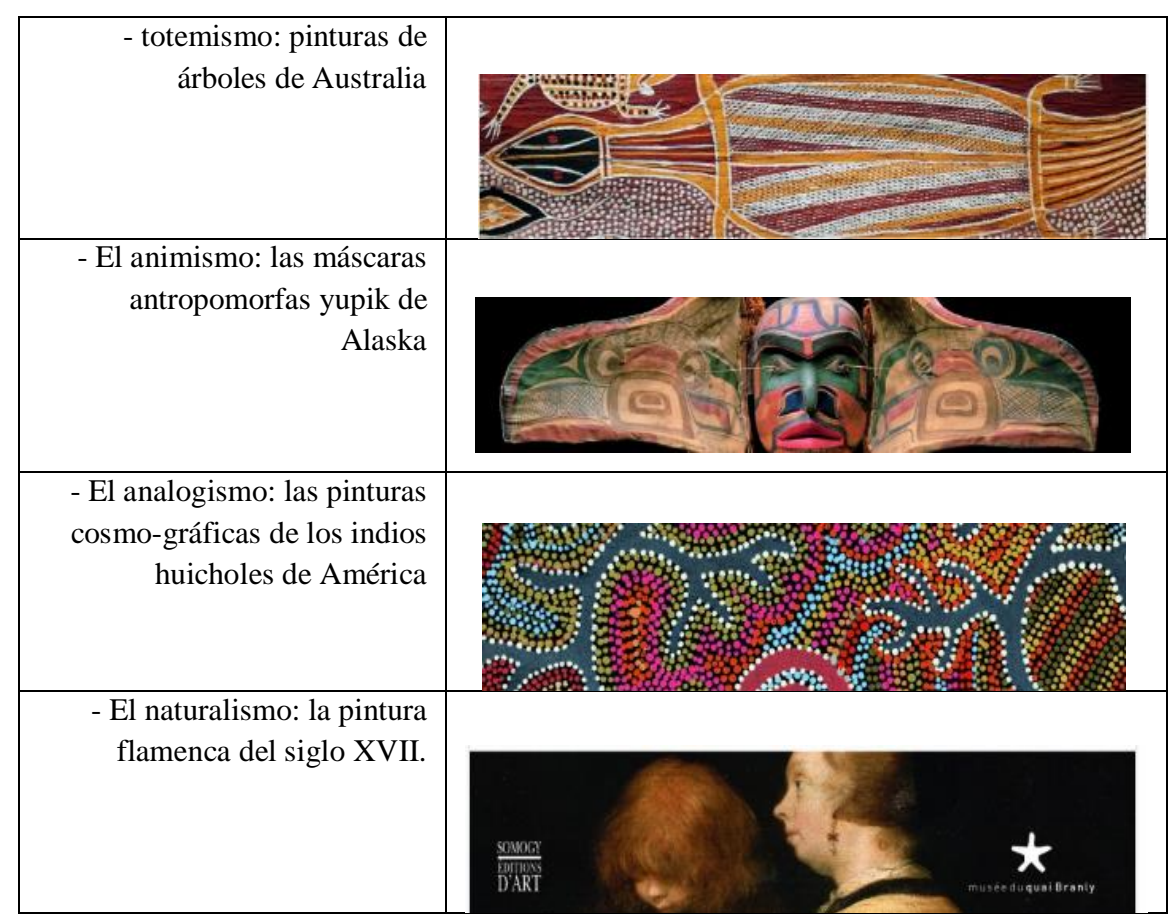

Ilustración 2: Rutas ontológicas planteadas por Descola

Fuente: http://www.somogy.fr/livre/la-fabrique-des-images?ean=9782757203224

Las rutas ontológicas que propone Descola no son sistemas puros ni están exclusivamente ubicados geográficamente o étnicamente, ni son una secuencia evolutiva, las diferentes ontologías podrían coexistir y cohabitar. En la sociedad actual predomina la actitud ontológica naturalista, pero puede convivir con posturas animistas. El motivo por el cual se trae en este ejercicio reflexivo los modelos propuestos por el antropólogo Philippe Descola, es primer lugar porque dichos modelos parten de la preocupación por la dicotomía naturaleza cultura, y segundo porque plantea alternativas teóricas de cómo incorporar a lo humano lo no-humano, planteando una multiplicidad de relaciones que los humanos mantienen con los no-humanos. La perspectiva que plantea Descola, desde sus estudios etnográficos, puede dar luces a la comprensión de comportamientos depredatorios cuando se privilegia una sola ruta ontológica o bien para encontrar en ellas formas de pensamiento y de relaciones que aporten soluciones a la crisis ambiental. 


\section{Vivieros de Castro y su Propuesta de Perspectivismo Amerindio como Alteridad Radical}

De acuerdo a González (2016) entre las líneas actuales de la antropología se encuentra una variante que reivindica la alteridad y el pensamiento del "otro" como entrada a la apertura ontológica y la revisión de principios y axiomas propios del naturalismo occidental. Esta propuesta se ha identificado con el antropólogo brasilero Eduardo Viveiros de Castro quien habla de "tomarse en serio al otro".

una llamada a aceptar hasta las últimas consecuencias las premisas ontológicas ajenas, su realidad y su alteridad, evitando someterlas a puntos de referencia externos a ellas mismas, o a consideraciones semánticas que las reduzcan a meras representaciones, y por tanto neutralicen su potencialidad para generar no sólo conocimiento sino también mundos (Viveiros de Castro, 2010, citado en González, 2016, p. 104).

Lo anterior implicaría poner al mismo nivel las concepciones de las naciones originarias al nivel de las teorías filosóficas, lo que para Ingold (1992) citado en González, (2016, p. 105) sería, hacer de la antropología una "filosofía con la gente dentro", en Viveiros de Castro sería que los discursos de los nativos narran no solo de sus sociedades o de sus mentes sino, principalmente de sus mundos, por ello la cosmogonía indígena siempre es ontológica: lo cual brinda una clara necesidad de viraje ontológico; por ello a su vez plantea el autor que "la antropología es la ciencia de la auto-determinación ontológica de los pueblos del mundo" (Viveiros de Castro 2003 citado en González, 2016, p. 105). 
Se parte de la premisa de la necesidad de abandonar la ficción de una ontología única, que sería en palabras de Viveiros de Castro, una ontología euro-americana, para así descubrir la multiplicidad de ontologías que existen. Dentro de esta variedad según González (2016), se encuentran trabajos de autores como el propio Viveiros de Castro, Marisol de la Cadena, Philippe Descola ya descrito anteriormente, Carlos Fausto, Laura Rival, Anne-Christine Taylor y Aparecida Vilaça, que han realizado "revisiones contemporáneas del animismo" por ejemplo en estudios amazónicos. El animismo ya comentado arriba en referencia a los presupuestos de Descola, es un término que fue acuñado para referirse a que algunos pueblos otorgan intencionalidad, subjetividad y por tanto personeidad a seres o entidades no humanas. Descola reaviva el concepto para “designar disposiciones humanas y atributos sociales a los seres naturales con intención de regular las relaciones con ellos" (González, 2016, p. 107).

Viveiros de Castro comenzó a desarrollar los postulados del perspectivismo amerindio en los años 80 cuando trabajó con las comunidades de Araweté en el Estado de Pará, grupo TupiGuaraní contemporáneo, pariente (lejano) de los Tupinambá, en el Brasil (Viveiros de Castro, 2013, p. 13). Es así que en su libro la mirada del Jaguar, Viveiros referencia que toda su investigación fue contrapunteada por la investigación indígena de la "naturaleza" de él mismo, queriendo decir con ello que, en la interacción, muchas veces son los "blancos" quienes resultan siendo estudiados por los indígenas. Menciona el autor que en su investigación no tenía una gran pregunta teórica que lo guiara desde el inicio, simplemente siguió y acompañó a los intereses de los Araweté fluctuando al ritmo que iba surgiendo en la interacción con ellos, así de este modo comienza su postura sobre el perspectivismo (Viveiros de Castro, 2013, p. 15). 
Inicialmente en el estudio sobre los Araweté el antropólogo inició con un modelo del perspectivismo -proceso de ponerse (o de encontrarse puesto) en el lugar del otro- teniendo, por ejemplo, que el canibalismo tupi-guaraní, podría ser interpretado en general, como un proceso por el cual se asume la posición del enemigo. El autor rápidamente se da cuenta que éste era un perspectivismo que todavía era de él mismo, era un concepto de él y no de los indios. En su reflexión se da cuenta que el concepto está ahí, pero es él quien lo fórmula, por ejemplo, cuando postula que el canibalismo tiene que ver con el cambio de perspectivas, el cual no es formulado por los indígenas (Viveiros de Castro, 2013, p. 15).

Después en los años noventa, junto con su discípula, Tânia Stolze Lima y con base en el material que ella estaba analizando, comenzaron a definir el complejo conceptual del perspectivismo; "la concepción indígena según la cual el mundo está poblado de otros sujetos, agentes o personas, más allá de los seres humanos, y que perciben la realidad de manera diferente a los seres humanos" (Viveiros de Castro, 2013, p. 16). El interés era identificar en diferentes culturas indígenas elementos que le permitiesen construir un "modelo", para contrastarlo con el naturalismo característico de la modernidad europea.

La proposición presente en los mitos indígenas es: "los animales eran humanos y dejaron de serlo, la humanidad es el fondo común de la humanidad y de la animalidad" (Viveiros de Castro, 2013, p. 17). De acuerdo a Viveiros de Castro, la mitología occidental es lo contrario: "los humanos éramos animales y “dejamos” de serlo, con la emergencia de la cultura" (Viveiros de Castro, 2013, p. 17). En nuestra forma evolucionista de ver el mundo es una condición genérica la animalidad: "todo el mundo" es animal, "sólo que algunos (seres, especies) son más animales que otros: 
nosotros los humanos somos evidentemente los menos animales de todos" (Viveiros de Castro, 2013, p. 17). Al contrario, en las mitologías indígenas:

Todo el mundo es humano, sólo que algunos de esos humanos son menos humanos que los otros. Varios animales están muy lejos de los humanos, pero son todos o casi todos, en el origen, humanos o humanoides, antropomórficos o, sobre todo, “antropológicos”, es decir, se comunican con (y como) los humanos (Viveiros de Castro, 2013, p. 17).

Todo esto, como se ha expuesto a lo largo de este ejercicio reflexivo, va a converger en la actitud que usualmente llamamos "animismo", en palabras de Vivieros: "la presuposición o intuición pre conceptual (el plano de inmanencia, diría Deleuze) de que el fondo universal de la realidad es el espíritu" (Viveiros de Castro, 2013, p. 18).

Lo anterior es explicado por Viveiros de Castro, al abordar situaciones tales por ejemplo cuando los indios dicen que "los jaguares son personas", lo cual dice algo sobre el concepto de jaguar y también sobre el concepto de "persona". Según el autor, "los jaguares son personas porque, al mismo tiempo, la jaguaridad es una potencialidad de las personas, y en particular de las personas humanas" (Viveiros de Castro, 2013, p. 22). En nuestra cultura afirma el antropólogo, hay contextos (medicina, zoología, biología) donde se acepta la proposición, "los seres humanos son animales", inversa a la proposición "los animales son personas". La primera proposición es tomada como perfectamente evidente, y ello no conlleva a que se trata a un vecino como se trataría por ejemplo a un buitre o cualquier animal. Por ello considerar del mismo modo, que los jaguares son personas no significa que "si un indio encuentra un jaguar en la selva va necesariamente a tratarlo como se trata a un cuñado humano" (Viveiros de Castro, 2013, p. 22). 
Retomando la explicación que defiende el antropólogo Viveiros de Castro apoyado en el animismo de Descola, e inspirado en las recopilaciones de Tânia Stolze Lima en los noventa, se pregunta si es que la Humanidad es la que se comparte “¿cómo puede ser que seres humanos y animales no se reconozcan?" (González, 2016, p. 108). Para esto el autor plantea la fórmula que complementa al animismo: "..la diferencia de fisicalidades, de cuerpos, de naturalezas, sobre la que se sustenta el perspectivismo. Los cuerpos son el modo por el cual la alteridad es aprehendida como tal" (González, 2016, p. 108). Así, para Viveiros los cuerpos mutan en base a la perspectiva o los puntos de vista y es donde se origina "el correlato ontológico del perspectivismo: el multinaturalismo" (González, 2016, p. 108).

Es así, como el antropólogo brasilero es el que más rompe o intenta como dice Ruiz-Serna (2016, p. 197) socavar los paradigmas radiocéntricos y epistemológicos de la filosofía occidental, la estructura occidental multiculturalista que como afirma Blaser (2009): “la misma distinción del mundo (naturaleza) y su representación (Cultura) continúa siendo afirmada como un universal" (Blaser 2009 citado en Ruiz Serna, 2016, p. 201)

Ampliando más acerca del perspectivismo amerindio Viveiros de Castro, se aprecia que la noción de que los animales son personas, es una idea común a muchas cosmologías indígenas, y esto no significa que los nativo americanos estén afirmando que los animales son personas como nosotros. El sentido común nos dice y sabemos, incluyendo a los nativos, que el animal es animal y que la persona es persona, pero bajo ciertos puntos de vista, en determinados contextos, para los indios tiene todo el sentido decir que algunos animales son personas (Viveiros de Castro, 2013, p. 21). 
Poniendo esto en un ejemplo, para los indígenas los jaguares son personas, pero también son jaguares, los jaguares son efectivamente jaguares, pero tienen un lado oculto que es humano:

Por el contrario, cuando se dice "las pirañas son peces" no se está diciendo que tienen un lado oculto que es ser pez. Cuando los indios dicen que "los jaguares son personas", esto nos dice algo sobre el concepto de jaguar y también sobre el concepto de "persona". Los jaguares son personas porque, al mismo tiempo, la jaguaridad es una potencialidad de las personas, y en particular de las personas humanas (Viveiros de Castro, 2013, p. 21).

El perspectivismo no es una forma de relativismo, afirma Viveiros en diálogo con (Stolze Lima. En el pensamiento de los indígenas un relativismo sería por ejemplo, que se dijera que para los cerdos todas las otras especies son en el fondo cerdos aún cuando parezcan humanos, jaguares, yacarés, etc. (Viveiros de Castro, 2013, p. 23). El autor tomó prestado el termino "Perspectivismo" de la filosofía para así considerar un aspecto muy característico de varias cosmologías amerindias: “el mundo está poblado por muchas especies de seres (además de los humanos propiamente dichos) dotados de conciencia y de cultura y, en segundo lugar, de que cada una de esas especies se ve a sí misma y a las demás especies de un modo bastante singular” (Viveiros de Castro, 2013, p. 36).

Cada especie se ve a sí misma como humana, viendo a las demás como no humanas, esto es, como especies de animales o de espíritus. Otro ejemplo que ilustra el perspectivismo se encuentra en los jabalíes (seres que vemos como jabalíes), también se ven como humanos, cuando ellos ven, las frutas silvestres que comen como si fuesen plantas cultivadas, y nos ven a los humanos como si fuéramos espíritus caníbales (pues los cazamos y los comemos) (Viveiros de Castro, 2013, p. 36). 
De acuerdo a Viveiros de Castro (2013) los conceptos que se derivan de este modelo perspectivista son:

-La forma corporal de cada especie es una ropa o envoltorio que oculta una forma interna humanoide.

-los chamanes son los únicos individuos capaces de asumir el punto de vista de más de una especie además de la propia.

-La humanidad reflexiva de cada especie, la caza y el consumo de carne animal son empresas metafísicamente delicadas, jamás libre de connotaciones caníbales.

Lo anterior se fundamenta en que: "todo esto se basa en un presupuesto fundamental, el de que el fondo común de la humanidad y la animalidad no es, como para nosotros, la animalidad, sino la humanidad" (Viveiros de Castro, 2013, p. 36). Lo anterior deja completamente de lado la idea occidental de separacion entre cultura y naturaleza, es una forma de reunificar siendo la humanidad, es decir, en este caso la cultura, el común denominador y más bien diferentes naturalezas (multinaturalismo) con posibilidades diversas de tejer entramados hacia una cultura humana (incluyendo a los no humanos).

De allí que la interacción entre humanos propiamente dichos y otras especies animales es, desde el punto de vista indígena, una relación social, o sea, una relación entre sujetos. Por eso Viveiros de Castro confirma que:

Entre las consecuencias filosóficas más interesantes de esta doctrina perspectivista indígena está la concepción de las relaciones entre "Naturaleza" y "Cultura" radicalmente distinta de aquella que tiene vigor, en versiones históricamente variables, en la tradición occidental (desde el par physis/ nomos de la Grecia antigua al par nature/société del Iluminismo) (Viveiros de Castro, 2013, p. 37). 
El perspectivismo, en resumen, es una cosmología que piensa un universo habitado por diferentes tipos de agentes subjetivos, tanto humanos como no humanos, cada uno dotado con el mismo tipo de alma, es decir, el mismo conjunto de capacidades cognitivas y volitivas. La posesión de un alma similar, implica la posesión de conceptos similares, que determinan que todos los sujetos ven las cosas de la misma manera. En particular, los individuos de la misma especie (Viveiros de Castro, 2004, p. 6). Las especies se ven unas a otras (y solo unas a otras) como los humanos se ven a sí mismos, es decir, como seres dotados de figura y hábitos humanos, viendo su cuerpo y aspectos de comportamiento en forma de cultura humana.

Dicha diferencia de perspectiva, no es una pluralidad de puntos de vista de un solo mundo, sino una sola visión de mundos diferentes los cuales no puede derivar desde el alma, ya que este último es el fundamento original del ser:

Más bien, tal diferencia se localiza en las diferencias corporales entre especies, para el cuerpo y sus afectos (en el en el sentido de Spinoza, las capacidades del cuerpo para afectar y ser afectado por otros organismos) es el sitio y el instrumento de la diferenciación ontológica (Viveiros de Castro, 2004, p. 6).

Esta postura implica la sustitución de "perspectiva" por "social". Nuestra propia etnoantropología, está enraizada en una ontología "moderna" que es multiculturalista y uninaturalista, el perspectivismo presenta una imagen antropológica constituida por la cosmopraxis amerindia en la forma de una teoría perspectiva con una "personalidad transespecífica", que es, por el contrario, unicultural y multinatural. (Viveiros de Castro, 2004, p. 3). De acuerdo al antropólogo brasilero basado en su contacto con los indígenas del amazonas brasilero, la concepción amerindia supondría una unidad espiritual y una diversidad corporal, o, 
en otras palabras, una "cultura" y múltiples “naturalezas". En este sentido, el perspectivismo no es el relativismo como lo conocemos, un relativismo subjetivo o cultural, sino un relativismo objetivo o natural, un multinaturalismo (Viveiros de Castro, 2004, p. 6). El atrevido planteamiento del investigador se explica así: “en otras palabras, el perspectivismo supone una epistemología constante y ontologías variables, las mismas representaciones y otros objetos, un solo significado y múltiples referentes” (Viveiros de Castro, 2004, p. 6). 


\section{Capítulo III: Acercamiento al Pueblo U'wa}

Para ampliar el problema del tipo de racionalidad como causa primera o bien como base de la crisis ambiental, en la que se fundamenta todas las matrices histórico-culturales. Se presenta el pueblo indígena U’wa como sustento para la reflexión de este documento, inicialmente con estudios sobre su cultura, desde acercamientos de la antropología simbólica y luego desde sus luchas políticas de defensa de su territorio que develan un pensamiento que se opone a la postura depredatoria del medio natural.

La comunidad U’wa se ubica en los departamentos de Boyacá, Norte de Santander, Arauca y Casanare; se puede decir que históricamente son un grupo intermedio entre los grupos de habla chibcha del altiplano y los grupos de habla arawak de los Llanos orientales (Rochas Vivas, 2010, p. 374).

Hoy en día la población U’wa se encuentra distribuida en tres departamentos, siendo el de Boyacá con el de mayor población correspondiente al 60\%, seguido por Norte de Santander con $27.7 \%$ y Santander con $11.6 \%$, Mientras que, por municipios, el de Cubará concentra alrededor del 48.46\% de toda la población, seguido de Toledo (20.71\%), Güicán (12.24\%), Chitagá (6.9\%), Concepción (6.6\%) y Cerrito con un 5\% respectivamente. Es significativa la presencia del pueblo U’wa en Boyacá, principalmente en los municipios de Cubará y Güicán. En el departamento de Santander con los municipios de Concepción y Cerrito. En Norte de Santander con el municipio de Toledo y Chitagá. (Asou’was, 2013, p. 38).

A continuación se presenta la distribución poblacional: 


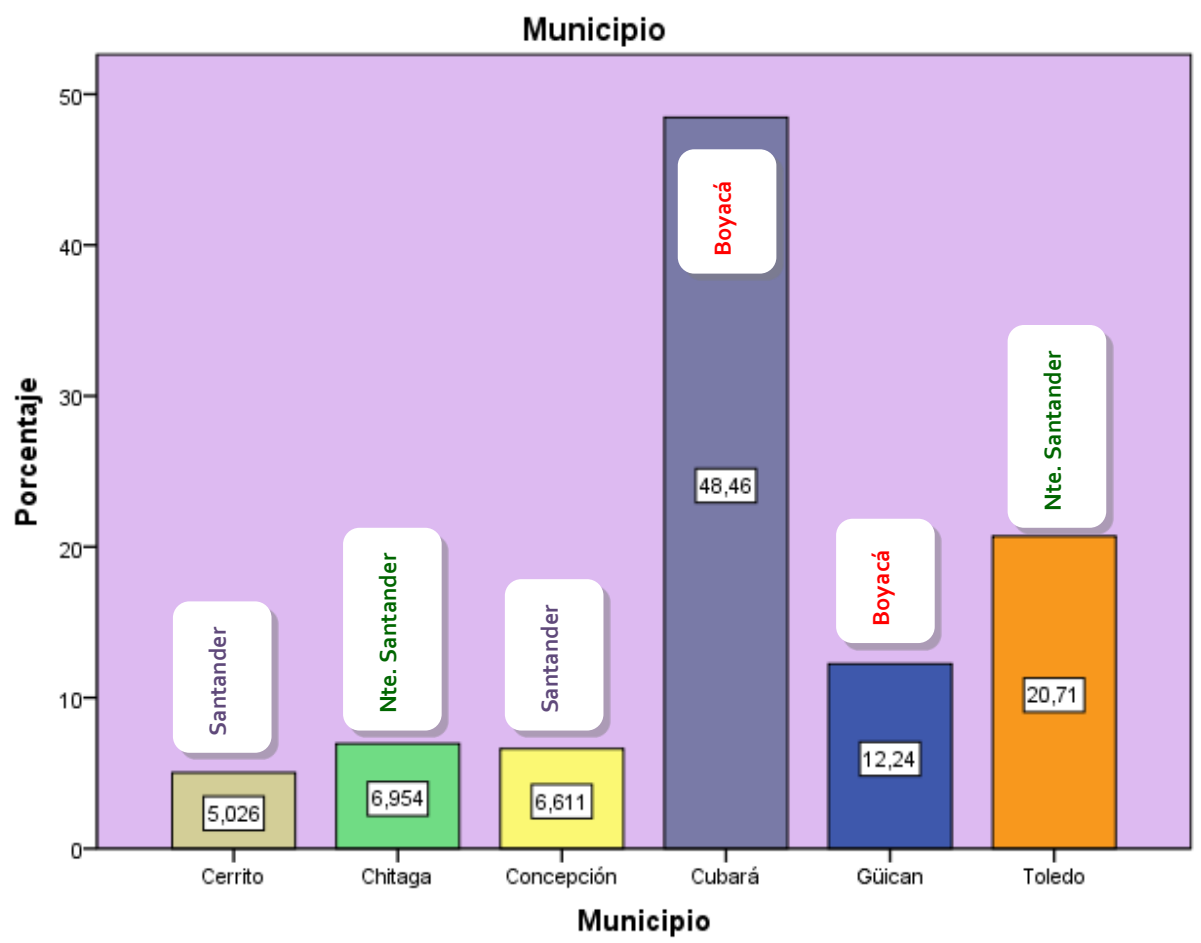

Ilustración 3: Distribución poblacional del Pueblo U'wa

Fuente: Asou'was, 2013, p. 40

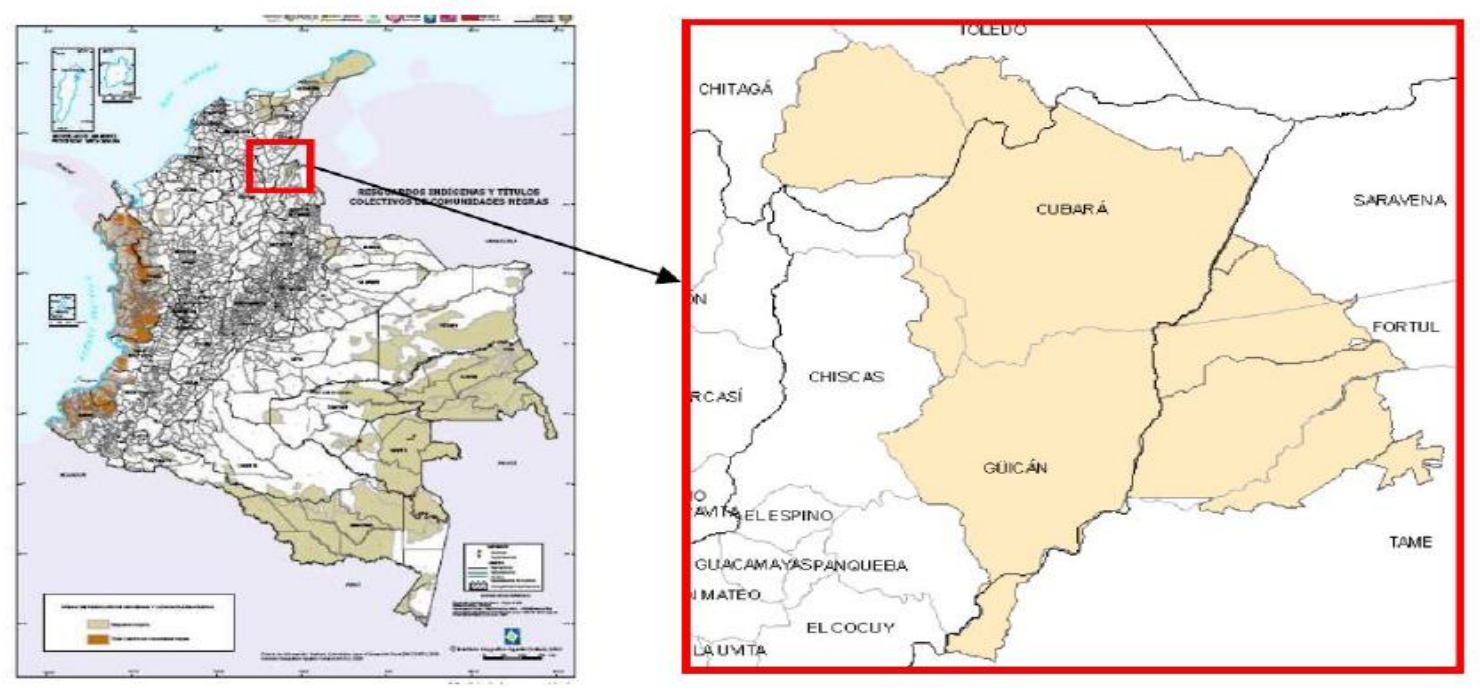

Fuente: IGAC SIG-OT

Ilustración 4: Ubicación geográfica de comunidades U'wa

Fuente: Mapa 1. Ubicación Geográfica del Resguardo Unido U'wa. (Asou'was, 2013, p. 34). 
Los U’wa se conocen también como tunebos, un apelativo que en la colonia fue "sinónimo de indios" en la zona de la Sierra Nevada del Cocuy o Zizuma (también conocida como Sierra Nevada de Chita, Güicán o Chiscas). La denominación U’wa se ha generalizado desde finales del siglo XX, y traduce "la gente", "la gente que piensa" y, más específicamente, "la gente inteligente que sabe hablar" (Falchetti A. M., 2003, p. 17).

Ampliando más sobre la denominación Tunebo éste puede provenir de túnindro: "pagar", ya que los tunebos hacen énfasis en el pago de carácter ritual intercambiando ofrendas (Falchetti A. M., 2003, p. 18). Pero tunebo también podría provenir de tunaba, o también llamados los cocuyos (insectos que despiden luz durante la noche) - Pyrophorus, ya que los U'wa realizan muchos rituales estacionales nocturnos. Entonces los U'wa o tunebos son aquellos que vuelan, cantan y bailan y alumbran por la noche tal como lo hacen los tunaba o cocuyos (Falchetti A. M., 2003, p. 17).

Se considera a la Sierra Nevada del Cocuy como centro cosmogónico y ceremonial de antiguos U’wa. Según Rochas Vivas (2010, p. 374) se presume que hubo al menos dieciséis clanes agrupados en ocho parejas. Hasta 1976 existían ocho clanes U'wa. En años recientes solo se identifican seis. En 1998, Correa escribió: "actualmente hay seis clanes (Andreses o Mojicones, Tegría, Cobaría, Bócota, Unkaría, Sínsiga; y se mencionan extinguidos los Unkasía o Betoyes y Bachira) citado en Rochas Vivas, (2010, p. 374). Sin embargo, la actual distribución de su población se organiza en cabildos, dirigidos por una autoridad y también, debido al proceso colonizador, las comunidades fueron atomizadas, reducidas a precarias e insuficientes tierras, provocando cambios drásticos en la organización social y territorial. Han desaparecido clanes por ejemplo aquellos que estaban en la frontera del territorio U'wa como son: los Bethuwa del Sarare 
y Venezuela, los Rubalisraya Güicán y los Shimuwa de Santander. También desaparecieron grupos muy relacionados con los U’wa como los Guane y los Lache (MEN, 2001, p. 18).

Según Ann Osborn ${ }^{5}$ (1995, p. 26), cuatro grupos se distribuyeron alrededor de la vertiente nororiental de la Sierra Nevada (2.000 a $3.000 \mathrm{msnm})$ y otros cuatro estuvieron en las tierras bajas (2.000 a $500 \mathrm{msnm}$ ). Los actuales U'wa realizan actividades en diferentes pisos térmicos, lo que implica cierta movilidad estacional. Para la autora, no se trata de la famosa verticalidad andina inducida por factores económicos - a la manera de los análisis de John Murra en el caso de los Andes centrales (Murra, 1975, p. 61)-; para los U’wa la práctica de la agricultura vertical se basa en su cosmología, es decir, no se trata de una intención exclusivamente material, por la cual los U’wa utilizan diferentes ambientes a diferentes alturas a lo largo del año como focos o centros para realizar en estas zonas sus ceremonias y celebraciones de acuerdo a los cambios entre equinoccios y solsticios.

Los cobarías o kubaruwa son el equivalente de los kogui en la otra Sierra Nevada, parece ser el clan más prestigioso ya que en Cobaría se realizan las grandes ceremonias de los mitos cantados, algunos de los cuales estudió y mostró Ann Osborn (1985, p. 45), para quien los indígenas de ambas Sierras Nevadas - Cocuy y Santa Marta- se asemejan por compartir varios rasgos, por ejemplo una misma familia lingüística, la distribución geográfica alrededor de una Sierra Nevada, las labores en tierras agrícolas a diferentes alturas, la organización social en parejas, las deidades simbolizadas por cumbres de las montañas y las lagunas (sitios asociados con los

\footnotetext{
${ }^{5}$ Ann Osborn: Sussex, Inglaterra 1933-Bogotá, Colombia 1988. Vino a Colombia en 1958. Conoció el país durante sus viajes y excursiones de montañismo y se fue interesando por estudiar las sociedades que vivían en las zonas aisladas de su geografía. Procedió entonces a hacer estudios de antropología y llevó a cabo su primer trabajo de campo a principios de la década de los sesenta entre los kwaiker en Nariño. Durante este período y en etapas posteriores de su carrera, recibió apoyo y estímulo de profesores, tanto en Colombia como en Inglaterra, que apreciaron su gran capacidad para el trabajo de campo y estimularon sus esfuerzos. Ingresó al London School of Economics y en 1967 obtuvo el diploma de postgrado en antropología social. Se menciona en especial porque el estudio que hizo junto con los U’wa es un aporte importante al conocimiento que se tiene de ellos, al menos desde la antropología simbólica.
} 
actos de las deidades) y los principios de niveles del mundo conceptual y de inversión (Osborn, 1985, p. 140).

De acuerdo a las investigaciones realizadas por Ann Osborn en los años 80, para los U’was el universo comprendía dos esferas: un mundo de arriba, el cual es seco, luminoso y con fuego. Un mundo de abajo que es oscuro, húmedo y vacío. Los dos mundos estaban estáticos y separados. Luego se movieron y al encontrarse los dos mundos formaron el mundo del medio. De esta manera cuando los indígenas realizan sus ritos cantan sus mitos empiezan refiriéndose a este momento inicial y se hace énfasis en su significado inicial (Osborn , 1995, p. 73). Cada mundo está identificado con colores: el mundo de arriba es blanco y el mundo de abajo es rojo. Cuando se mezclan surgen el color azul y el color amarillo.

La dicotomía arriba/abajo entonces se presenta agrupando al mundo de arriba los colores blanco y amarillo y al mundo de abajo rojo y azul. Al mezclarse el rojo y blanco que son los extremos surgió el mundo del medio, que está compuesto por Tikaiya (Azul) que tiene mayor proporción de rojo y tawaiya (amarillo) que tiene mayor proporción de blanco.

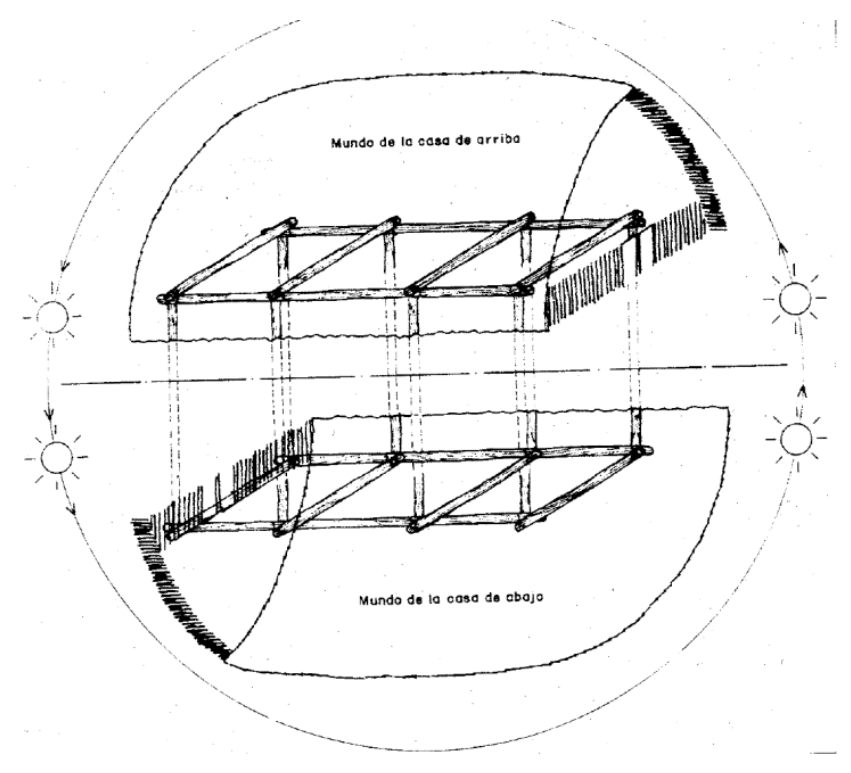


Ilustración 5: La Tierra según la visión de los Kubaruwa

Fuente: Osborn, A. (1995), las cuatro estaciones, Ed. Banco de la república, museo del oro, pág. 75.

El pensamiento U'wa, como expone Cardale de Schrimpff (1988) acerca de lo que la antropóloga Ann Osborn estudió sobre la cosmogonía U’wa, relata sobre la deidad Kanwara quien ordena a sus sobrinos maternos, las tijeretas, que vuelen por todo el mundo y pueblen. Hacen tres vuelos, siempre en sentido este-oeste, cantando lo que parecen ser los nombres de los sitios y lugares prominentes en el paisaje que sobrevuelan. La autora propone la hipótesis de que las tierras sobre las cuales vuelan las tijeretas es el territorio antiguo de los U'wa e incluye su territorio actual, el de grupos relacionados, y tal vez regiones que los U'wa visitaban en viajes de aprendizaje. Este mito no es solamente, una expresión literaria, sino que impulsa a la investigación arqueológica, la cual permitió localizar varios de los antiguos asentamientos U'wa sobre el costado noroccidental de la Sierra Nevada del Cocuy, con sus respectivos sitios ceremoniales. (Cardale de Schrimpff, 1988, p. 12).

En su tesis doctoral Ann Osborn (1985) relata cómo las comunidades U’wa realizan rituales cantando sus mitos y siguiendo una secuencia anual en un manejo estacional en diferentes ecosistemas siguiendo actividades agrícolas y no agrícolas que se dan paralelamente. Sus investigaciones muestran cómo el ritual, el mito, la agricultura, la cosmología y otras actividades gestoras de vida se interrelacionan e interactúan. La hipótesis de la antropóloga es que la mitología es tan esencial para la supervivencia como lo es, por ejemplo, la agricultura y que, por tanto, se la debe considerar como condición necesaria para la existencia física y cultural. (Osborn A. , 1995, p. 85). Para el pueblo U’wa el territorio, se maneja desde la cosmovisión. Para los Kubaruwa, las 
situaciones de la vida o los procesos vitales suelen tener tres posiciones posibles: Las oposiciones contrastantes que se derivan de mundos extremos y las intermedias. (Asou'was, 2013, p. 85).

De acuerdo a Espinal \& Montenegro (1963), a lo largo del año los grupos de la comunidad U’wa, particularmente los Kubaruwa, cambian de residencia varias veces. Distinguiéndose tres zonas con diferentes rangos de altitud: las tierras bajas, el piedemonte y la zona de montaña. También, explotan una zona del llano cercano. En general se puede decir que son tres tipos de zonas: llanuras, montaña y tierras altas. Cada una tiene diferentes características: las llanuras o tierras bajas son planas se denominan bosque muy húmedo tropical, las zonas de montaña o piedemonte son una transición entre las tierras bajas y las tierras altas, su ecosistema es bosque muy húmedo montano bajo. Las tierras altas constituyen las montañas escarpadas con bosque muy húmedo montano, dichos autores basan su clasificación ecológica según Holdridge (Espinal \& Montenegro 1963, citados en Osborn, 1995, p. 32).

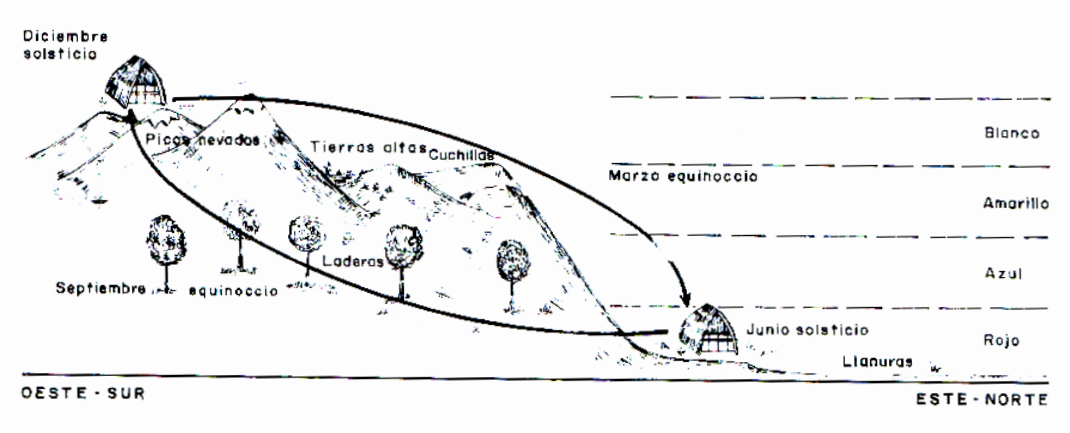

Representación del camino anual del Sol

Ilustración 6: Desplazamiento de los U'wa a lo largo del año siguiendo el movimiento del Sol Fuente: Osborn, A. (1995), las cuatro estaciones, Ed. Banco de la república, museo del oro, pág. 80. 
Zona de Tierras bajas (bosque muy húmedo tropical): Los Kubaruwa, según Osborn (1995), cultivan yuca y maíz en sus parcelas de las tierras bajas y llanuras, al igual que en las otras zonas, solo que de variedades diferentes. En las llanuras cazan, pescan, recogen miel y cera de abejas sin aguijón. Sin embargo, no poseen tierra ni vivienda construidas. Actualmente, este ecosistema ha sido invadido por los blancos para el levante del ganado, afectando seriamente sus prácticas de desplazamiento, además de que los ríos de estas zonas se han contaminado por el uso de la dinamita exterminando peces y otros animales. Las consecuencias han sido una disminución de fuente proteica en su dieta, prácticamente desde los años 40 , teniendo como consecuencia generaciones con desnutrición y propensión a las enfermedades.

Zona de Piedemonte (bosque muy húmedo montano bajo): Los Kubaruwa, habitan en lomas que poseen abundantes piedras y arena, rodeado de bosque tropical, la zona posee pendientes con abundantes quebradas y riachuelos. Lastimosamente, los cinturones de bosques y las tierras agrícolas en descanso bajo el bosque regenerador han sido desmontadas por los blancos, quienes las consideran "tierras baldías" y las usan para establecer potreros para ganadería como lo hicieron la Misión de San Luis Chuscal (Osborn A., 1995, p. 36).

Zona de montaña (bosque muy húmedo montano): en esta zona el clan Kubaruwa vive cerca al pueblo de Cobaría, estas zonas poseen suelos poco aptos para la agricultura, los grupos indígenas procuran dejar esta área bajo la protección del bosque, que sirve de techo. Ellos usan los recursos del bosque procurando que no se agote su potencial regenerativo: no cortan árboles cuyos frutos sean alimento de algún animal silvestre prefieren entonces usar otros árboles para leña.

Zona de Tierras Altas: Zona muy agreste que tienen las cumbres de la sierra nevada del Cocuy, tiene grandes formaciones rocosas y frecuentes derrumbes. Esta zona es usada por los 
U’wa como fuente de caña para elaborar canastos y coronas ceremoniales. En las altas montañas se encuentran lugares donde los U’wa dejaban sus productos de intercambio, se marchaban y luego regresaban a recoger sal y ruanas a cambio.

Las descripciones de las tierras mencionadas, contextualizan el desplazamiento que hacen los U’wa particularmente del clan Kubaruwa, alternando su residencia en estas tierras. Así ellos están en las tierras altas cuando el sol está en las bajas (más hacia el sur y al este, lugar del solsticio), y están en las tierras bajas cuando el sol está en las altas (más hacia el norte y al oeste). Los desplazamientos residenciales desde las tierras bajas hasta las tierras altas, se hacen en sincronía con los diferentes rituales que se reparten a lo largo del año, dividido en cuatro estaciones:

En su libro las cuatro estaciones, Ann Osborn (1995) describe las diferencias a lo largo del año:

La estación que va de mayo a julio que abarca el solsticio del norte: el Reowa (soplada del solsticio) "se llama "florescencia" pues en esta época las mujeres que pueden procrear están en la última etapa de su embarazo. Se realizan ayunos donde sólo se consumen alimentos del bosque propios de la estación, como nueces, frutas, etc. En general la vida normal se trastoca o invierte.

La siguiente estación va de agosto hasta principios de noviembre cubre el equinoccio otoñal, en esta estación se celebra el ritual del Aya, se denomina "cosecha" ya que se cosecha maíz en el asentamiento de la montaña. En esta estación nacen la mayoría de los niños. Los productos cultivados son el sustento de las personas. Hay gran actividad social debido a la celebración de los rituales, las uniones y los matrimonios. Durante este tiempo los Kubaruwa, se encuentran en el pueblo de la montaña y no salen hasta que se acaba la estación. 
La estación que abarca el siguiente ciclo corresponde al solsticio del sur y es cuando los U'wa celebran los mitos cantados el ordenamiento de las abejas y la soplada del alucinógeno. Esta estación se denomina "semillas" aquí se separan los hombres de los asentamientos de las tierras bajas donde en este momento se encuentran para irse a recolectar y a comerciar. Se celebran rituales de iniciación femenina, (kokora) separando a las jóvenes que entran a la adolescencia.

La última estación comprende el equinoccio invernal, se celebran mitos cantados sobre la transformación de los estados asexuales en sexuales, se celebra el paso de estados indiferenciados a estados de diferenciación entre animales y hombres. Esto último se hace determinando que alimento debe consumir cada uno. Los mitos asociados a esta estación son La zorra y la zarigüeya y la soplada de los animales. La estación se denomina "siembra" dado que la gente siembra el maíz que va a servir en la siguiente estación donde se celebra el Reowa o soplada del solsticio, el Aya, se siembra alrededor del pueblo de la montaña y cuando los hombres y mujeres se unen para producir los embarazos.

Como se aprecia la lógica con la que viven las comunidades U’wa particularmente los Kubaruwa, estudiados por Ann Osborn, muestra una secuencia cíclica en el espacio y tiempo: semilla, siembra, florescencia, cosecha, los cuales corresponden a su vez a la sincronía de sus mitos cantados: El Aya, el ordenamiento de las abejas, la soplada del alucinógeno, la zorra y la zarigüeya y la soplada de los animales. Simultáneamente como organización social los U’wa se sincronizan con estos ciclos estacionales para desarrollar su vida: uniones matrimoniales, producción de embarazos, nacimiento de los niños. El siguiente diagrama muestra cómo se organizan a lo largo del año lo anterior las diferentes estaciones: 


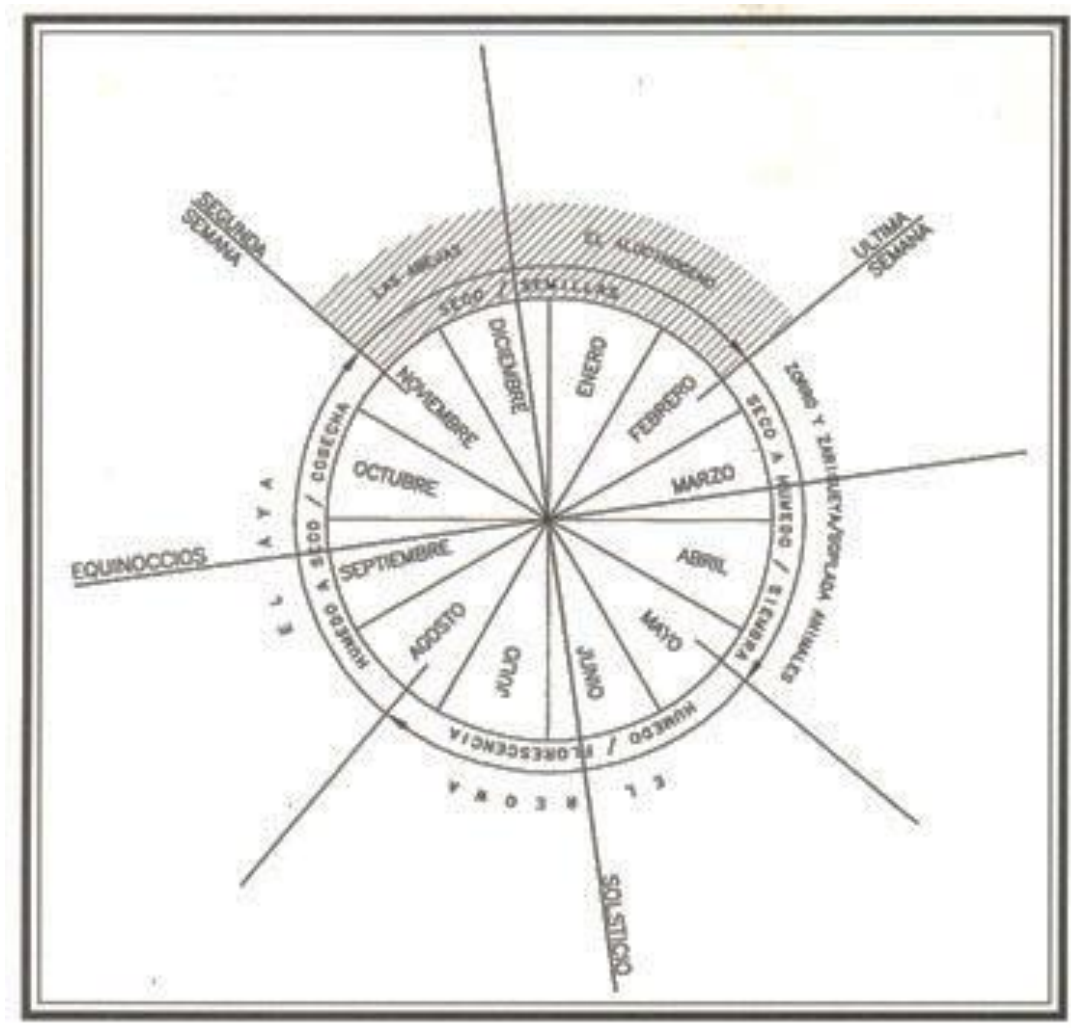

Ilustración 7: Ciclo anual de la celebración de los mitos cantados

Fuente: http://www.banrepcultural.org/node/26572boletin del museo del oro No. 43 de 1997 la ofrenda y la semilla

En estos ciclos mencionados y estudiados juiciosamente por la antropóloga inglesa Ann

Osborn, en los años setenta y parte de los ochenta, se tiene que la interacción con la naturaleza es sincrónica a los ciclos de la tierra alrededor del sol, a lo largo del año.

A continuación, se muestra el calendario de los Kubaruwa que represente las actividades relacionadas con cada uno de sus rituales con sus respectivas estaciones. 


\section{CALENDARIO KUBARUWA}

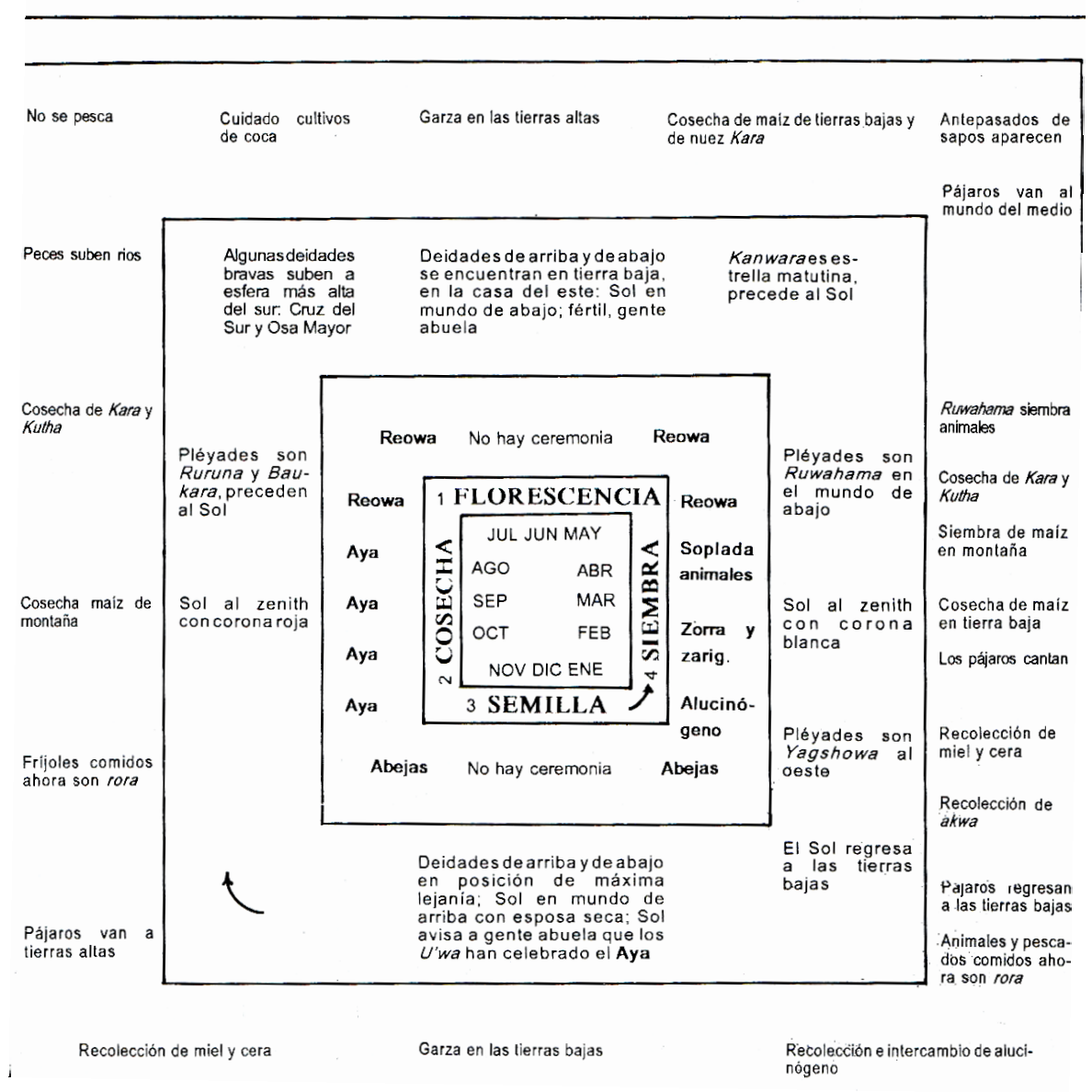

Ilustración 8: Calendario Kubaruwa

Fuente: Osborn, A. (1995), las cuatro estaciones, Ed. Banco de la república, museo del oro, pág. 116

De acuerdo a Arango (2000) los U'wa nos recuerdan que el hombre y el mundo es el microcosmos, parte de un todo y que una de las razones del ser humano, como organismo pensante y ser social, es cuidarlo, celebrarlo y expresarlo a través de la cultura como elemento germinador, desentrañador y comunicador mediante el recurso de lo imaginario, lo simbólico, el arte y el deseo. Para ellos el eje de la biodiversidad es la cultura, que se traduce, también en identidad, territorialidad, destino histórico, memoria y, sobre todo, valores éticos y estéticos (Arango, D. 2000, citado en MEN, 2001, p. 11) 
De acuerdo a Falchetti (1997) en su artículo de la Ofrenda y la Semilla:

Los U’wa integrarían el metal en las múltiples asociaciones con que su mitología explica sus orígenes y el orden del universo, en un mundo ceremonial y en el intercambio. El mito de Las Abejas del clan Cobaría, en el contexto de la mitología U’wa, permite establecer la presencia del oro y de la cera de abejas, junto con otros elementos, en un contexto de transformaciones en que la "semilla", base de la continuidad de la existencia, aparece como tema central. El concepto de "germinación de la semilla" estaría implícito en la ofrenda ritual, a través de la cual los humanos asumen su papel de propiciar la continuidad de la vida y el equilibrio del universo. Para los U’wa la gente es también "semilla", creencia que estaría en la base de ciertas prácticas funerarias, como la momificación, tendiente a "proteger y preservar la semilla" para permitir su renacimiento. (Falchetti A., 1997, p. 31).

Finalmente, según Ann Osborn la cultura U’wa tiene una alta condición intelectual y de conocimiento. Para la antropóloga es una "sociedad acostumbrada al estudio, cuyos chamanes eran verdaderos maestros; en la cual, las actividades de la producción material y la producción intelectual, de la apropiación del mundo a través del trabajo y su apropiación por medio del pensamiento, no se han separado todavía” (Vasco Uribe, 1995, p. 1).

\section{Pensamiento U'wa}

"Nuestro territorio es el corazón del mundo, por él corren las venas que alimentan el universo, si se destruye se desangra el mundo"

(Entrevista Berito Cobaría)

En los apartados anteriores hay un despliegue de características etnográficas de los U’was, los cuales son un recorrido desde la antropología simbólica, que contextualiza a estos herederos de sistemas de pensamiento milenarios, en los cuales se busca el equilibrio y la relación armónica 
con el medio natural y social. A diferencia de la perspectiva occidental el mundo natural para los pueblos originarios está incluido en sus sistemas culturales de manera integral. De tal forma que la perspectiva de la historia que tienen los pueblos ancestrales y particularmente el pueblo U’wa se fundamenta en hacer valer sus creencias (Falchetti A. M., 2005, p. 46).

Se puede notar, además, que su perspectiva ha forjado una conciencia histórica dinámica, que es a la vez pragmática y mítica. Pragmática porque han preservado todos sus rituales, sus creencias autóctonas, para defender su identidad, su territorio y su propia supervivencia. Mítica porque es su forma de explicar el mundo, la manera como guían todos los aspectos de su vida. Esta forma de interpretar el mundo presenta una realidad multidimensional, la cual une de manera indisoluble el ser humano, el entorno y lo sagrado (Falchetti, 2005, p. 46).

Los U’wa vienen desde siglos atrás cuidando del mundo físico y espiritual, logrando una armonía entre el pueblo y el medio ambiente; articulado concepciones sobre la naturaleza, la tierra, los animales, los dioses y los hombres, todo esto narrado en grandes ciclos de mitos cantados que se celebran continuamente a lo largo del año. Formando un complejo de sistemas asociado a prácticas sociales, individuales y colectivas, que rigen el trabajo agrícola, patrones nutricionales, consumo de alimentos, el ceremonial de los ritos de paso y procreación (Cabrera 1998 citado en MEN 2001, p. 15)

La ruta ontológica del naturalismo moderno (que se menciona en los primeros apartes de este documento), la realidad es percibida en dimensiones separadas unas de las otras, por ello no hay integración entre la organización social y el mundo natural, persiste más bien una visión utilitaria de la naturaleza y en general una disección de la realidad. La tradición occidental valida su conocimiento a través de la transmisión escrita, en códigos con una estructura específica que 
pasa por el filtro de la racionalidad del paradigma dominante: la comprobación científica. La tradición nativo-americana, reproduce su cultura a través del lenguaje oral usando símbolos, metáforas y mitos. Estos con su propia estructura y coherencia en el contexto de los rituales. Estos últimos son para los indígenas la forma como construyen su historia y su vida social, soporte de la relación armónica con el medio natural.

La diferencia entre estas dos formas de pensar, ha conducido a los pueblos autóctonos a defender, preservar, resistir y proteger sus costumbres y sus rituales. La tradición occidental impuesta por los españoles ataca los rituales y los califica de hechicería, por tanto, los indígenas en el pasado mantenían en secreto todas sus actividades rituales.

Muchas son las evidencias de las persecuciones de los españoles a los rituales de los indígenas U’wa y ejemplo de ello se encuentra en la narración sobre la resistencia liderada a mediados del siglo XVIII por el Cacique de Chisgas, Diego Casiano, quien fue calificado de hechicero y adivino:

... se amotinaron los indios confederándose con los indios infieles y los de Güicán, armados con chafarones y palos. Siendo las cabezas de este motín un indio llamado Custodio Español y otro nombrado Diego Casiano y los descendientes de éste, moviéndose a este exceso contra el suplicante porque ha procurado, con muy moderados castigos, traerlos al pueblo y sacarlos de los públicos pecados de concubinatos, hechizos y otras muchas supersticiones y vicios... para cuyo fin es que han tomado lo más áspero de los montes y riscos como lugar más acomodado para su brutal vida, siendo el más principalmente los trae a estos lugares el ya enunciado Diego Casiano, nominándose para esto cacique y fundador del pueblo (Informe del cura de Chiscas, Ignacio Navarro, Archivo General de la Nación. Caciques e Indios: 58:255r-255v, Citado en Falchetti, 2003, p. 149). 
Los U’wa han luchado por hacer valer su visión de la realidad, su ontología, mostrando que es igualmente legítima como lo es la visión de los españoles, tanto en tiempos coloniales, como hoy en día, su lucha y resistencia siguen intactas.

Así lo expresan en sus escritos modernos: "si no cantásemos el mundo se desmoronaría, se vendría abajo... cantamos también para los blancos, para que ellos en su mundo puedan seguir viviendo" (MEN, 2001, p. 17). También se expresa en el texto U’wa: visión y testamento (2002):

Nosotros nacemos siendo hijos de la tierra, eso no lo podemos cambiar los indios ni tampoco el hombre blanco. Más de mil veces y de mil formas distintas les hemos dicho que la tierra es nuestra madre, que no queremos ni podemos venderla, pero el hombre blanco parece no haber entendido, insiste en que cedamos, vendamos o maltratemos nuestra tierra, como si el indio también fuera hombre de muchas palabras (Werjain Shita, 2002, p. 1)

La narración que hacen los indígenas de los eventos lo hacen desde sus propias concepciones o modelos usando el conocimiento mítico ancestral, que pertenece más a esferas religiosas y espirituales. Por ello es tan difícil que su pensamiento sea aceptado y menos leído como filosófico. Pero lo importante aquí es que esta forma de pensar le otorga los elementos para lograr la continuidad de la vida. En palabras de Falchetti (2005):

La mitología se apropia de la historia y la interpreta según su propia estructura. En el proceso, el relato mítico ancestral también se transforma a sí mismo para dar sentido a la historia en una realidad concreta, y para que contribuya a restablecer el equilibrio en situaciones de crisis en la vida social. Porque la evocación indígena de los hechos no puede desligarse de la situación social, económica y política imperante en el momento, que influye en la interpretación particular de las tradiciones, en esa construcción de la identidad que conlleva una intención política, pero que busca, además, desde 
la estructura misma del pensamiento mítico, un ajuste entre maneras distintas de interpretar la historia (Falchetti, 2005, p. 63).

Compartimos con Falchetti (2005), su mirada del mito el cual, tiene contextos mucho más amplios que aquellos que se proponen desde simplificaciones y estereotipos que funcionan alrededor del mito viéndolo en posición opuesta al logos. El mito tiene el mismo papel como el logos porque mediante éste se expresa la racionalidad de un pueblo que de manera simbólica se pregunta sobre lo mismo que hacen los filósofos, es decir, sobre el origen del universo, sobre el sentido de la existencia y de la realidad, sobre nuestro papel en el mundo y cómo asumir la existencia particular. En últimas sobre una ontología propia.

\section{Visión de la Realidad de los U'wa}

Lo anterior se conecta con lo ilustrado al comienzo del presente documento acerca del binario naturaleza y cultura señalado por Descola (2011) y Viveiros de Castro (2013) mostrando cómo los U’wa tienen también su propia visión de la realidad, entendida ésta de acuerdo a Burman (2017) como "una serie de premisas, una serie de conocimientos e ideas sobre lo que existe y como llega a existir, es decir sobre la naturaleza de la realidad" (Burman, 2017, p. 160).

Es por esto que para sustentar lo anterior demos la palabra a los U’wa a través del líder espiritual de unas de las comunidades de los U’was, Berito Cobaria en una entrevista en video, realizada por la Socióloga Yolanda Parra (2013) donde ésta le pregunta:

¿Cuál cree usted que sigue siendo la fortaleza de los pueblos indígenas en América latina, en México, Bolivia y Perú que es lo que mantiene fuerte a los pueblos, cuál es el mensaje para el mundo para la sanación de la tierra, para los problemas del cambio climático del medio ambiente, o sea qué es lo que los pueblos indígenas pueden aportarle al mundo? 
A lo que responde Berito Cobaría: Mire hermanita Yolanda ojalá que entendemos y escuchamos distintos países, hermanos por esa razón nosotros la civilización, la inteligencia y los conocimientos están atadas a estas cordilleras, allí para arriba donde nacimos Cobarias hay 2.500 metros de altura, y esas son nuestras casas de la naturaleza, esas son de los creadores, esas casas son de toda la naturaleza de agua. Civilización está allí (señala las montañas). Civilización es pensar cómo te habla las aguas cómo te hablan los bosques montañas estos, es un capital, esta selva es un capital de la naturaleza (Cobaria, B. citado en Parra; Y. 2013).

Como se aprecia se evidencia una relación estrecha con la naturaleza donde para los U’wa ésta es un sujeto con el que se puede interrelacionar, a la que se le puede hablar. Ellos tienen una concepción de civilización en la cual se incluyen a los seres no-humanos, tal como lo señala el líder espiritual. En el pensamiento de los U’wa se evidencia que la naturaleza posee interioridad capaz de dar respuesta a interlocuciones, por ello permite comunicarse con los humanos, tal como lo afirma Berito Cobaria en la misma entrevista: "Si nosotros vamos a la montaña los bejucos esos son comunicaciones, teléfonos, cables líneas todo ...” (Cobaria, B. citado en Parra; Y. 2013).

También en su visión de la realidad de los U’wa se aprecia la necesaria integración a la madre tierra pero no como una simple relación de afecto, sino como una relación diferente a la de dominación que impone el naturalismo moderno, donde la naturaleza es objeto, en la ontología U’wa la relación es de respeto y profunda sacralidad:

La ley de nuestro pueblo se diferencia de la del blanco, porque la ley del Riowa (hombre blanco) viene de los hombres y esta escrita en el papel, mientras que la ley de nuestro pueblo fue Sira (Dios) quien la dictó y la escribió en el corazón de nuestros sabios Werjayas (Chamanes). El respeto a lo vivo y a lo no vivo, a lo conocido y a lo 'desconocido' hace parte de nuestra ley: Nuestra misión en el mundo es narrarla, cantarla y cumplirla para sostener el equilibrio del universo. Nuestra Ley 
U'wchita es uno de los postes que sostienen al mundo. Nuestra ley es tan antigua como la misma tierra, nuestra cultura se ha organizado siguiendo el modelo de la creación, por eso nuestra ley de la tierra y la tierra es una sola. ¡Nuestra ley no la vamos a morir $\ldots . . .$. si existen leyes del hombre blanco que protegen a la madre tierra y a sus guardianes los pueblos indígenas, ique se cumplan!, si no se cumplen, se consideran no escritas (Werjain Shita, 2002, p. 2).

Otro aspecto que se encuentra en el pensamiento U'wa que que su capacidad de ponerse en el lugar del otro para comprenderlo pero sobre todo para respetar las diferentes formas de pensar. Se aprecia en el texto U’wa así:

Para el indio la tierra es madre, para el blanco es enemiga; para nosotros sus criaturas son nuestras hermanas, para ellos son sólo mercancía. El Riowa (hombre blanco) siente placer con la muerte, deja en los campos y en sus ciudades tanto hombres tendidos como árboles talados en la selva. Nosotros nunca hemos cometido la insolencia de violar iglesias y templos del Riowa pero ellos sí han venido a profanar nuestras tierras, entonces nosotros preguntamos, ¿Quién es salvaje? (Werjain Shita, 2002, p. 2).

Algunos jefes blancos se han horrorizado ante su pueblo de nuestra decisión de suicidio colectivo como último recurso para defender nuestra madre tierra, una vez más nos presentan como salvajes, pero ellos buscan confundir, buscan desacreditar. A todo su pueblo le decimos: El U'WA se suicida por la vida, el blanco se suicida por monedas ¿Quién es salvaje? La humillación del blanco para con el indio no tiene límites, no solo no nos permite vivir, también nos dice como debemos morir... no nos dejaron elegir sobre la vida... ahora elegimos entonces sobre la muerte (Werjain Shita, 2002, p. 4).

Lo anterior se nos muestra como una apuesta a la igualdad ontológica en reclamo a las continuas invalidaciones de los mundos de los nativos americanos por parte del proyecto 
colonizador de quinientos años y que aún perdura. De acuerdo a Kohn (2013) se resalta que cuando el U’wa dice que "todas las criaturas son sus hermanas", se está planteando una discusión ontológica de fondo y es el reconocimiento de realidades configuradas a partir de perspectivas nohumanas (Kohn 2013 citado en Ruiz-Serna, 2016, p. 199). En ese sentido Ruiz-Serna nos interpela diciendo que esta idea rompe la vieja matriz occidental y rompe con la idea de la naturaleza es un objeto únicamente, y pasa a ser sujeto.

Entre las consecuencias y posible aporte de esta reflexión a través del pensamiento indígena U’wa, es que como menciona Kohn (2013) el análisis de las interacciones entre humanos y nohumanos (animales y plantas entre otros) es un elemento clave en el concepto denominado ecología de subjetividades, en la cual los propios mundos perceptuales de los no-humanos están en relación y son reconocidos con el mundo de los humanos, descentrando así al anthropos (Kohn, 2013 citado en Ruiz-Serna, 2016, p. 199). Esto a su vez desemboca en que resulta importante comprender no sólo “cómo los humanos conciben y representan a los animales y al mundo exterior, sino también analizar la manera en que éstos ven el mundo y representan a los humanos” (Ruiz Serna, 2016, p. 199). En palabras de Viveiros de Castro sería el perspectivismo amerindio, donde la visión del hombre se descentra y como lo enuncia Villareal (2013):

el perspectivismo no supone la pluralidad de representaciones del mundo, sino la pluralidad de perspectivas. Todos los seres se representan el mundo de la misma manera, lo que cambia es el mundo que ven, y esto, como ya hemos visto, está determinado por su forma corporal de existencia". (Villareal, 2013, p. 14).

Se aprecia que los U’wa no hacen distinción entre ellos y los animales, puesto que están conformados por las mismas propiedades originales. Tomando datos etnográficos recogidos por Ann Osborn (1990), tanto los hombres como los animales obtuvieron en un tiempo primordial 
diversas sustancias alucinógenas, y de acuerdo con las mezclas específicas de cada una de ellas se obtienen sus "diferencias relativas". Para ilustrar mejor esto Pineda (2005) relata la siguiente anécdota: Un oso atacó y mató a una criatura que había sido momentáneamente dejada al borde de un cultivo; el animal no tuvo la culpa -relataron los U’was a la antropóloga Ann Osborn- ya que vio a la niña (la criatura) como maíz y estaba hambriento. El oso fue abatido, para que no cometiese el mismo error, y se le dio un entierro como gente pues en el mundo de abajo, él se volvería un ser humano (Osborn 1990, citada en Pineda, 2005, p. 28).

En consonancia con lo anterior en el documental denominado Indígenas U'wa Colombia Guardianes de la Madre Tierra (CIDEMOS, 2016), donde un anciano que es guía espiritual que solo habla uwcuwa expresa en traducción: "Ruira (madre tierra) es la que da equilibrio a nuestro territorio, sin ella no hay vida en este planeta...:" mas adelante se entrevista a Juan Soto Cabildo Comunidad de Bachira también expresa:

para nosotros el petróleo es la sangre de la tierra, es la sangre de la tierra, que por eso existe y no se consume el agua. Nosotros los indígenas sabemos que al sacar el petróleo pues puede filtrar el agua y se puede acabar el agua encima de la tierra. Por eso decimos que no a la explotación petrolera cerca al nevado y en la tierra. Eso es para los pueblos indígenas la explotación petrolera causa deterioro y se acabara el mundo también. (Soto, J, citado en CIDEMOS, 2016).

También, encontramos en U'wa: visión y testamento (2002) donde se afirma:

Sabemos que el Riowa (hombre blanco) le ha puesto precio a todo lo vivo y hasta la misma piedra. Comercia con su propia sangre y quiere que nosotros hagamos lo mismo en nuestro territorio sagrado con ruiria, la sangre de la tierra a la que ellos llaman petróleo... todo esto es extraño a nuestras costumbres... todo ser vivo tiene sangre: Todo árbol, todo vegetal, todo animal, la tierra también y 
esta sangre de la tierra (ruiria, el petróleo) es la que nos da la fuerza a todos, a plantas, animales y hombres. (Werjain Shita, 2002, p. 3)

Retornando al concepto de alteridad radical sorprende cómo el indígena si puede "girar" es decir, pueden realizar una apertura, con el fin de tratar de entender al 'otro'. Es interesante destacar que dado que en el pensamiento de los U'was - el anthropos es descentrado, esto es, establecen relaciones sociales con los no-humanos, no les queda difícil entonces, entender o tratar de entender a otro ser humano que no comparta las mismas realidades o pensamientos. Lo anterior se aprecia cuando afirman:

Pero nosotros le preguntamos al Riowa ¿Cómo se le pone precio a la madre y cuanto es ese precio?. Lo preguntamos no para desprendernos de la nuestra, sino para tratar de entenderlo más a él, si el oso es nuestro hermano, más lo es el hombre blanco. (Werjain Shita, 2002, p. 2)

Mas adelante... Quizás los U'wa podamos seguir nuestro camino, entonces así como las aves hacen sus largos viajes sin nada a cuesta, nosotros seguiremos el nuestro sin guardar el más pequeño rencor contra el Riowa porque es nuestro hermano, seguiremos cantando para sostener el equilibrio de la tierra no sólo para nosotros y nuestros hijos, también para él porque la necesita, en el corazón de los U'wa hay preocupación por los hijos del hombre blanco. Si así lo quieren, tampoco retendremos el aire que nace en nuestras montañas, él podrá seguir tonificando la alegría de los niños blancos y nuestros ríos deberán partir de nuestras tierras tan limpias como llegaron, entonces la pureza de los ríos les hablarán a los hombres del mundo debajo de la pureza de nuestro perdón. (Werjain Shita, 2002, p. 6)

La relación que los U’was tienen con la tierra es una declaración normativa con la cual se configura la vida, asi los rituales que incluyen ayunos son tomados como evaluaciones para ver 
“cómo les contesta la naturaleza". Asi lo explica mejor Berito Cobaria cuando se le pregunta por la ley de origen que los gobierna

¿La ley del origen dónde está... La ley de origen está en el cielo y esta abajo en el planeta Ruya, otros mundos o planetas donde están nuestros abuelos... Hoy nosotros queremos profundizar más la regla y la norma y derechos. La norma hoy que estamos luchando por un derecho territorial y por tener la vida. Es porque el creador nos dio todas las herramientas y nosotros cada año evaluamos, cada año vamos evaluando; a ver cómo nos contesta la naturaleza verdad, esa es la única coordinación que seguiremos. Así mi civilicé yo, nadie me dio ni un lapicero, a mí me dio la civilización con un charazo en la mano para limpiar la caña. (Cobaria B, citado en Parra; Y. 2013).

Nosotros vivimos en equilibrio con nuestro territorio, siguiendo las indicaciones que Sira les dio a nuestros Werjayas a través del transcurrir de los tiempos.

\section{Conectando las Diferentes Perspectivas}

Ampliando la comprensión U’wa de la realidad, y conectándola a lo que Estermann (2006) nos señala, su filosofía está emparentada con la filosofía andina de las regiones de Perú y Bolivia, al afirmar que la entidad básica es la relación y no el "ente” sustancial. Para el autor o más bien para la lógica andina explicada por él, es la relación, su estructura primordial la que permite a los entes constituirse como 'entes' (Estermann, 2006, p. 126). O bien lo que para Viveiros de Castro apunta como la interacción entre humanos propiamente dichos y otras especies animales es, (desde el punto de vista indígena), una relación social, o sea, una relación entre sujetos (Viveiros de Castro, 2013, p. 37). 
De acuerdo a lo anterior se muestra un texto en la introducción del Documental Indígenas U'wa Colombia - Guardianes de la Madre Tierra:

Tierra no solo es el pedazo de polvo del que nacimos. Tierra es Historia. Tierra es madre. Tierra es Padre Eterno. Por eso todos somos hermanos, hombres, animales y cosas. Tierra es Dignidad. Tierra es el Espiritu de nuestros pueblos y de nuestros antepasados. Tierra es vida según la visión indígena: tierra es historia pero para el blanco es difícil entenderlo así. Berito Cobaria Lider espiritual del pueblo U’wa. (Cobaría, B. citado en CIDEMOS, 2016)

Llama la atencion como termina el anterior pensamiento, consientes de la asimetría en el pensamiento U’wa y la del pensamiento del blanco. En esa premisa donde la Tierra es todo para los indígenas U’wa se aprecia un afan por la conservación, por la protección de la naturaleza por eso ellos dicen:

Juan Soto Cabildo Comunidad de Bachira: Nosotros decimos guardianes porque nosotros no nos gusta explotar, nosotros lo único en lo que pensamos es en cuidar y vivir en ella, por eso decimos que somos guardines, porque nosotros nunca porque nosotros, no decimos vamos a acabar aquella montaña vamos a acabar aquellos cerro... no. Somos cuidadores. (Soto, J. citado en CIDEMOS, 2016).

Locutora: Sira el padre celestial les entregó a los U'wa la tierra para que la cuidaran y protegieran, por esta razón este pueblo indígena tiene el conocimiento para entender, leer, escuchar y dialogar con la naturaleza. (CIDEMOS, 2016)

Los indígenas U’wa siguen principios que como Estermann (2006) señala son principios que se derivan del axioma de la relacionalidad, como son: la correspondencia, la complementariedad y la reciprocidad. Por ello se les permite afirmar que como lo menciona un miembro de la comunidad: 
Juan Soto Cabildo Comunidad de Bachira: Hay tres cosas de una vez vamos a la niña, de una vez a la naturaleza y al agua, esto es para que nunca se seque, ella haciendo estos rituales o estos cantos o estos homenajes, nunca se seca el agua, nosotros por eso lo hacemos cada tres meses o seis, lo hacemos constante cuando haya una niña adolescente, hacemos estos cantos y así mismo a la madre tierra. ¿Por qué hacemos eso a la niña?, porque ella es mujer y el agua es una mujer para nosotros y la madre naturaleza pues también es mujer. (Soto, J citado en CIDEMOS, 2016).

Se aprecia la correspondencia que hacen entre lo femenino y el agua, entre la madre y la naturaleza. Es interesante como se explica la correspondencia entre la civilización y el conocimiento y su relación con los elementos naturales tales como el ayo (hoja de coca), así lo ilustra de manera clara y sorprendentemente sencilla pero muy sabia, Berito Cobaria cuando expresa:

Nosotros nacimos con todo, nosotros nacimos con minas de sal, que llaman salineras. Y nosotros nacimos con derechos tierras y civilización con la planta que estoy comiendo. Yo felicito a mis hermanos bolivianos que tienen buena canal...

Mire este es nuestro papel (señala la hoja de coca) este es el papel que comemos, estoy echando, (a la boca) saco mi lapicero (saca el palito del calabazo) es mi lapicero y aquí saco tinta (se echa en la mano el contenido del calabazo) echo ayo aquí es donde se marca el casette (señala la cabeza) y aquí es donde se escribe (señala con su mano el corazón), son nuestros computadores y espiritualidad... (Cobaria, B. citado en Parra; Y. 2013).

El pensamiento de los U'wa no es algo que se comprende de manera abstracta, no se trata del nacimiento de las estrellas o de pensar sobre las cosas lejanas de la vida cotidiana, en esa cosmogonía se expresa el mundo concreto, el mundo de la vida en términos husserlianos. Dicha 
“cosmoontología" abarca la tierra, el territorio, los seres vivos, el pensamiento de las personas y los entes transcendentales que interactúan con el mundo cósmico, biológico y social.

Así se enuncia en la entrevista de Yolanda Parra a Daris Cristancho Activista y lideresa de la comunidad U’wa cuando le pregunta por el uso de la hoja de la coca:

Yolanda Parra: tu estas masticando coca que significa la coca esto para el pueblo U'wa

Daris: Para nosotros el ayo es como la parte en la cual nosotros podemos pensar, analizar y soñar, porque este es la parte que nos da como el poder de conexión, el poder de conexión con la parte espiritual ella nos lleva o conduce a que podamos conectar con la naturaleza y también poder conocer el bien y el mal. Entonces es algo que nos mantiene en equilibrio y en comunicación con la parte espiritual (Cristancho, D. citado en Parra; Y. 2013).

O bien cuando una niña presente la entrevista responde:

Yolanda Parra: Estamos en el recorrido del territorio U’wa, estamos acá en el rio Cobaría. Es un río que atraviesa el territorio y que marca el territorio de una de las comunidades más importantes y más sólidas, que es la comunidad de Cobaría. Hoy estamos dedicando este día al ayuno que el pueblo U’wa comienza o que comenzó hace dos días, para el equilibrio y el encuentro de todos los espíritus de los cuatro mundos como ellos los llaman. El mundo del aquí del ahora, el visible y el invisible.

Esta es una niña U’wa, que crece en la ciudad, Ingrid tú ¿por qué le rezas a los ríos? ¿Cómo le rezas a los ríos?... tú me dijiste que había que rezarles a los ríos... ¿Por qué?

Niña Ingrid: Le rezo, que los cuide bien y que nunca se sequen. (Ingrid citada en Parra; Y. 2013).

La respuesta es clara, para el pueblo U'wa su salvaguarda se garantiza en la medida que su territorio sea reconocido legalmente, que no sea intervenido y no se explote ninguno de sus recursos naturales. 


\section{Propuesta alterna de los U'wa a la Dicotomía Cultura-Naturaleza}

Dentro del pensamiento U’wa y más bien dentro de su concepción de la vida se encuentran aspectos que apuntan a incorporar la dimensión ecosférica (no-humanos, montañas y ríos) en su horizonte de realidad. Siendo esto una de las consecuencias más importante del pensamiento U’wa: la defensa de su territorio en torno a lo que llamaría Blaser (2009) algunos conflictos de distribución cultural, a la relación de las sociedades y la naturaleza (Blaser, 2009 citado en Ruiz Serna 2016, p. 194). Como lo afirma Escobar (2012) en cada relación social que los humanos establecen con los no-humanos, no solo para hacer uso de ellos, sino para constituirse con ellos en una comunidad surge entonces que "el principio centrado en los humanos, se expande para incluir a no-humanos (que pueden ir desde animales a montañas, pasando por espíritus, todo dependiendo de los territorios específicos). Consecuentemente, el terreno de la política se abre a los nohumanos". (Escobar, 2012, p. 7).

Lo anterior claramente se puede apreciar en la lucha U’wa contra la explotación petrolera en su territorio. Los hechos históricos nos muestran cuando en 1995 los U’wa ganaron una demanda para detener la explotación petrolera por la Oxy, a pesar de ello en febrero de 1997, la corte constitucional revierte el fallo de Corte Suprema. Los U’wa hicieron un llamamiento muy fuerte a la comunidad Internacional, en Europa, Estados Unidos y Latinoamérica. Así en 1997 la OEA y el Instituto de Resolución no violento de conflictos (Univ. Harvard), recomendó al gobierno colombiano, la suspensión de la explotación petrolera. Luego los U’wa ganaron el premio Goldman al medio ambiente. También, gracias a sus campañas con Amazon Watch, Rain Forest Action Network, Amazon Alliance y otras organizaciones lograron que Fidelity Investments, las 
cuales son principales accionistas de la Oxy, presionándola para que cesara la explotación. Lastimosamente, Ecopetrol reanudó las excavaciones en 2006 (Restrepo, 2007, p. 163).

Se sabe que dicho reclamo de jurisdicción sobre el derecho al territorio resulta fundamental ya que la defensa del territorio equivale a la defensa de la propia existencia físico-espiritual porque es en la tierra que se saca el sustento, pero también es el espacio donde yacen los ancestros, donde se reproduce la cultura, la identidad y la organización social de los indígenas (Berraondo, 2006, p. 471).

Ha habido un conflicto asimétrico entre las multinacionales petroleras y el pueblo U’wa, debido a que como Mario Blaser (2009) lo señala, las disputas tienen lugar porque entran en colisión diferentes puntos de vista del mundo: “no son conscientes de que cada uno de ellos está representado (y asumiendo) diferentes mundos” (Blaser 2009 citado en Ruiz Serna, 2016, p. 200). El antropólogo argentino habla de una “ontología política para dar cuenta de aquellas disputas por la definición misma de qué es lo visible, lo legítimo y lo legible en el mundo contemporáneo" (Blaser, M. 2009 citado en Ruiz Serna, 2016, p. 200). Se trata de conflictos ontológicos, pues no se trata de las diferencias en las visiones de la naturaleza de la realidad, lo que sería más bien un conflicto epistemológico, sino sobre el carácter mismo de lo que existe y puede ser conocido (Ruiz Serna, 2016, p. 200).

Asi los U’was lo expresan:

Todas sus ofertas económicas sobre lo que es sagrado para nosotros, como la tierra o su sangre, son un insulto para nuestros oídos y un soborno para nuestras creencias. ¡Este mundo no lo creó el Riowa ni ningún gobierno suyo, por eso hay que respetar! El universo es de Sira y los U'wa únicamente lo administramos, somos tan solo una cuerda del redondo tejido de la $u k u a$ (mochila), pero el tejedor es 
Él. Por eso los U'WA no podemos ceder, maltratar, ni vender la tierra ni su sangre, ni tampoco sus criaturas porque estos son los principios del tejido. Pero el blanco se cree el dueño, explota y esclaviza a su manera, eso no está bien: Rompe equilibrio, rompe Irokua. Si no podemos venderles lo que no nos pertenece, no se adueñen entonces de lo que no pueden comprar (Werjain Shita, 2002, p. 3).

Antes a la codicia y a la ignorancia le daban el nombre de acciones evangelizadoras o civilizadoras, ahora le llaman progreso. El progreso, ese fantasma que nadie ve y que se ha dedicado a aterrorizar a la humanidad... Antes el oscuro camino de saqueos, genocidio e injusticia contra nuestro pueblo era alumbrado con el cidral en nombre de Dios y de su Majestad, hoy es alumbrado con el petróleo en nombre del progreso y de la mayor de las majestades entre la mayoría de los no indígenas... el dinero (Werjain Shita, 2002, p. 5).

De allí que los U’was modernos han consolidado su ontología dentro y a veces en conflicto con la ontología naturalista occidental. Como se ha apreciado a lo largo de las premisas del pensamiento U'wa desplegadas en la presente reflexión, existe en ellos una preocupación constante por constituirse en los defensores y guardianes de la tierra. Como lo propone Escobar (2015) "la ontología política busca visibilizar las múltiples formas de "mundificar la vida" y la práctica política ontológica contribuye a defender activamente estos mundos” (Escobar A., 2015, p. 97).

La tarea final por parte de la ruta ontológica del naturalismo moderno occidental, -dado que es la dominante y le cuesta “girar”-, es la comprensión de las rutas ontológicas del animismo, totemismo y analogismo para descentrarse y visibilizar que existen territorios como menciona Escobar (2015) los cuales son espacios biofísicos y epistémicos a la vez:

Al mismo tiempo- donde la vida se enactúa de acuerdo a una ontología particular, donde la vida se hace 'mundo'. En las ontologías relacionales, humanos y no-humanos (lo orgánico, lo no-orgánico, y lo sobrenatural o espiritual) forman parte integral de estos mundos en sus múltiples interrelaciones (Escobar A. , 2015, p. 98). 
Finalmente, queda reconocer que de seguir con el ritmo de depredación pocas décadas en la tierra quedan para las futuras generaciones, por ello los U’wa y su forma de vivir y pensar son el recordatorio de la importancia de la indisoluble relación entre humanos y no-humanos en el mantenimiento de la vida sobre el planeta. 


\section{Conclusiones}

De acuerdo al objetivo general propuesto inicialmente, en relación a la reflexión sobre las causas de la crisis ambiental que se encuentran asociadas a un pensamiento depredatorio y que subyacen a la dicotomía entre cultura y naturaleza y después de haber revisado las posturas que se presentan como alternativas al binomio cultura y naturaleza a saber: filosofía andina presentada

por el filósofo suizo Josef Estermann, las intermediaciones realizadas por antropólogos como Descola y Vivieros de Castro a través de otros tipos de racionalidades y finalmente los U'was como comunidad indígena colombiana que con su forma de pensamiento y en su lucha política presentan una propuesta opuesta al pensamiento depredatorio. A continuación, se presentan las siguientes conclusiones:

\section{Crisis Ambiental Asociada al Pensamiento Predatorio}

De acuerdo a la intención inicial de esta reflexión se postula que el principal causante de la crisis ambiental es un cierto tipo de relación cultura y naturaleza que privilegia la dominación del hombre hacia ésta última, asociada a un pensamiento depredatorio en el que subyace la dicotomía entre cultura y naturaleza. Las modificaciones que el ser humano le ha infligido a la naturaleza tienen que ver sobre todo con el ritmo acelerado del uso de diferentes materiales que ha conllevando a generar enormes cantidades de residuos. Esta contaminación, como vimos, es extensiva y profunda; extensiva porque cada vez se amplía a más zonas en la tierra, en profundidad dado que inclusive se modifica el ecosistema (introducción de organismos modificados genéticamente). El otro problema que posee la relación del ser humano y la naturaleza es el grado de conciencia acerca del cuidado del ambiente pero que no logra crear prácticas y pensamientos diferentes; este último es el más grave pues se encuentra como en una especie de burbuja: se 
reconoce y se destaca la preocupación por el desastre ambiental, pero se renuncia a dejar los mismos patrones de desarrollo capitalistas, los cuales son precisamente las causas de la crisis ambiental. Por lo anterior, se intenta rescatar el grado de conciencia como parte de la problemática y como recurso que alimenta la posibilidad de contención. En el presente documento se acudió a matrices histórico-culturales estudiadas por autores como el filósofo Josef Estermann, los antropólogos Philippe Descola y Eduardo Viveiros de Castro, y el legado del pensamiento ancestral de la comunidad indígena U’wa, que presentan la realidad de una manera que intenta resignificar la naturaleza, mostrar otras formas de ordenar la realidad y detenerse en el entendimiento del otro incluyendo en este "otro" a los no-humanos.

\section{Ecosofía Andina}

El filósofo suizo Josef Estermann (2006), en el estudio de la filosofía amerindia, plantean un camino que muestran un tipo de relación cultura-naturaleza alterno al sistema de pensamiento capitalista de dominación de la naturaleza: extracción y acumulación. Como se señaló, para Estermann el posible origen de la dicotomía entre cultura naturaleza se encuentra en la raíz desmitificadora de la naturaleza de la tradición greco latina y en la tradición semita, que desacraliza el mundo, todo ello heredado por la modernidad como un permiso para profanar y secularizar el universo físico. Logrando con ello la total secularización y desmitificación del mundo material y de los seres no-humanos: la relación del espíritu occidental con la naturaleza es una relación instrumental y tecnomorfa (Estermann, 2006, p. 189). Teniendo claro el origen de esta fractura, el autor orienta la propuesta de la relacionalidad del todo (propia de la racionalidad andina) la cual es tomada en el presente estudio como un camino de unificación entre la cultura y la naturaleza, todo ello contrario al uso privilegiado de la lógica como instrumento de relación con la naturaleza como la tradición de occidente lo ha instalado en la modernidad; más bien el autor presenta (como 
alternativa o complemento a la lógica) a la comunión, se trata de formas ceremoniales A través de las que el hombre andino se relaciona con su entorno. Con este instrumento y como nueva forma de relación con el entorno, Estermann presenta a la filosofía andina como una experiencia concreta y colectiva del ser humano andino en su universo físico y simbólico, que luego en un estado más avanzado de revisión el autor afirma que dicha filosofía es "praxo-lógica dado que es una reflexión sistemática y metódica de esa experiencia colectiva” (Estermann, 2006, p. 74). Dicha experiencia que se propone por parte del hombre andino es intervenir el mundo de una forma no dominadora. Todo ello significa que el hombre andino escucha y obedece la estructura relacional con la que funciona la pachamama, no se ubica como un ente pasivo u anónimo, tampoco la cambia a su capricho o gusto, porque entiende que si lo hace también se ve afectado a sí mismo. En ese sentido el autor construye el concepto de "ecosofía andina", la cual comprende a la naturaleza como el todo de la realidad, puesto que la cultura está inmersa en ella, no es algo separado u opuesto, donde el hombre es ante todo un agricultor y no un productor, es un socio un cuidador, co-creador de la casa común de todos los entes, no es distinto ni superior a los demás no-humanos, éstos merecen un trato justo de acuerdo a su posición en el orden cósmico (Estermann, 2006, p. 193).

Por lo anterior, esta forma de pensamiento conlleva a un comportamiento que propicia el equilibrio en la existencia humana y no humana, que permite que las relaciones no sean únicamente de depredación y explotación, sino que se establecen mínimos acuerdos basados en los principios de relacionalidad del todo, correspondencia, complementariedad y reciprocidad, resolviendo el problema central de la crisis ambiental que es la depredación y la contaminación.

\section{Otras Formas de Ordenar la Realidad}


De otro lado, con este ejercicio exploratorio se quiso entonces, abordar otras formas de racionalidad que conduzcan a una resignificación de la naturaleza y de su relación con la cultura, y sus formas de transformación del entorno. En ese sentido se pusieron en la mesa de discusión los estudios y planteamientos de antropólogos como Philippe Descola y Viveiros de Castro. Descola propone diferentes rutas ontológicas para la comprensión de otras formas de ordenar la realidad y detenerse en el entendimiento del "otro" en la investigación antropológica. Donde ese "otro" incluye a los seres de la naturaleza no humanos. De igual manera, el antropólogo Viveiros de Castro, a través del "perspectivismo amerindio" plantea minar los paradigmas eurocéntricos de la filosofía occidental, contribuyendo al igual que Descola a la revisión e introducción de la alteridad radical en los estudios de la realidad en el marco de las relaciones sociales en el mundo, actuando como traductores del pensamiento de otras civilizaciones e intentan describir otro tipo de racionalidad que identifica pistas que ayudan a romper o sutura la dicotomía entre cultura y naturaleza.

\section{Naturalismo Moderno}

De acuerdo con la reflexión realizada a lo largo de este documento, la ruta ontológica naturalista occidental, que en sus premisas aborda a la naturaleza como un objeto de dominación, tal como lo afirma Descola, es la causante de la actual crisis ambiental. Es así que esta cuarta ruta ontológica que describe Descola: el naturalismo moderno, ha predominado en el pensamiento occidental y es entre otras el arjé que orienta el actuar propio del naturalismo moderno. Este considera la existencia de una naturaleza única y una multiplicidad de culturas y concibe que hay diferentes interioridades y un continuo evolutivo en las materialidades. Lo anterior quiere decir, que la distinción entre humanos y no-humanos es claramente el alma, la consciencia y la subjetividad. Dicha discriminación ontológica le da permiso de usar y ver a la naturaleza como un 
objeto, dado que, al carecer de alma o subjetividad, será “objeto" bien sea de conocimiento, de estudio o de explotación. Este tipo de visión propicia la separación irreparable entre cultura y naturaleza.

\section{Alternativas al Naturalismo Moderno}

Se plantea entonces una visión menos antropocentrista, en palabras De la Cadena (2015) se trata de concebir pluriversos, que incluyan en la fórmula a los no-humanos, como sujetos políticos con derechos no tanto de suyo propio, sino como condición de continuidad de la vida en este planeta. De acuerdo con esto, existen rutas ontológicas que son alternativas a la ruta ontológica del naturalismo moderno, aunque el calificativo "alternativas" se refiere más a que no son dominantes ya que no todos los pueblos en el mundo comparten el naturalismo como única ruta ontológica, encontrándose incluso híbridos. Estas rutas son propuestas por Descola (2011), dado que las relaciones de continuidad y discontinuidad entre naturaleza y cultura en el desarrollo de la antropología ha sido una preocupación de sus estudios investigativos. Entonces resulta importante mencionar los aportes de sus estudios en donde la naturaleza pasa a ser sujeto de una relación social y permiten concebir la multiplicidad de relaciones que los humanos mantienen con los nohumanos, basados en los criterios de poseer interioridad o materialidad (diferente de cuerpo y alma).

Para ello Descola plantea entonces, cuatro rutas ontológicas, de las que ya se mencionó a la cuarta el naturalismo, el autor plantea además al totemismo (basado en la continuidad de 'materialidades' e 'interioridades' entre humanos y no humanos); el animismo (basado en una continuidad entre humanos y no humanos en lo que se refiere a la 'interioridad', mientras que lo que los diferencia es su 'materialidad'); el analogismo (que postula una discontinuidad básica entre humanos y no humanos tanto en su 'materialidad' como en su 'interioridad'); y el mencionado 
naturalismo (que nos une a humanos y no humanos por una continuidad 'material' -el evolucionismo- y nos separa por la 'aptitud cultural' o por la diferente capacidad de interioridad alma-), siendo esta última la dominante en el contexto occidental.

\section{Visión Compartida: la Humanidad}

En la presente reflexión se resaltó la propuesta de la ruta ontológica animista, que para la crisis ambiental, se presenta como alternativa de solución, dado que dotar con características sociales a los seres que la tradición occidental ha encuadrado en la naturaleza como objetos (plantas, animales), posibilita una relación menos depredadora y más respetuosa con la misma. Es realizar un "giro" que permita centrar la cultura como el eje alrededor del cual giran las diferentes naturalezas, esto es el multinaturalismo y donde se tiene una humanidad como una condición o referencia compartida, una visión integralmente cultural de su medioambiente en razón de una interioridad como la de los humanos, pero diferente en razón de sus respectivas materialidades corporales.

Lo anterior desemboca en lo que Viveiros de Castro configuró como el perspectivismo amerindio, reafirmando la ruta ontológica animista. Donde lo que se comparte no es la animalidad con los no-humanos sino precisamente la humanidad. Por ello Viveiros explica que los humanos y no-humanos se reconocen, dado que se diferencian en sus corporalidades, pero coinciden en su humanidad: los cuerpos mutan en base a la perspectiva o los puntos de vista y es donde se origina el correlato ontológico del perspectivismo: el multinaturalismo. Esto último es que cada una de las especies se ve a sí misma y a las demás especies de un modo bastante singular: como humana. Esta es la fórmula para romper con la escisión o mejor para “coser” la división cultura - naturaleza, 
pues las diferentes naturalezas dejan abiertas posibilidades para tejer una única cultura humana, la que por supuesto incluye a los no-humanos.

\section{Transformación de la Vida: Semilla, Siembra, Florescencia y Cosecha.}

Desde el análisis del presente estudio se toma que el aporte del pensamiento U’wa es precisamente resaltar el enfoque animista y perspectivista con el que se mueven las comunidades U’wa, inclusive dando un paso más allá que se definiría como una relación ética integral con su entorno (lo que se entiende como aquello que abarca el cuerpo, la sociedad y la naturaleza). Los U’wa dan cuenta de un ejemplo vivo de una cultura que incluye a no-humanos en una relación no unicamente depredatoria, pues la tendencia de todas sus prácticas es a que la vida continúe, se mantenga y restablezca el equilibrio. Esto es algo recurrente y que se manifiesta con la idea de que la gente es "semilla", dado que en sí misma contiene todas las posibilidades para germinar y dar continuidad a la vida. En ese sentido el respeto por la vida en los U'wa es un concepto claro de su pensamiento.

Otro aspecto relacionado es la idea de intercambio que ocurre luego de la transformación de la "semilla" es decir, al dejar que la vida continúe, a la vez se están respetando los ciclos de la naturaleza. De otro lado las prácticas secuenciales y estacionales de desplazamiento a lo largo de los pisos térmicos para realizar sus rituales, sincronizar sus uniones, matrimonios y nacimientos al ciclo de la naturaleza (Semilla, siembra, Florescencia y Cosecha), hacen de esta cultura un modelo para una supervivencia sobre la tierra que si cumple con el precepto ecológico y aforismo de la periodista Barbara Ward": "Nos hemos olvidado de ser buenos huéspedes, de cómo caminar ligeramente sobre la Tierra como hacen sus otras criaturas.”

\footnotetext{
${ }^{6}$ Barbara Mary Ward (23 de mayo de 1914, Heworth, Yorkshire, Reino Unido- 31 de mayo de 1981, Lodsworth, Sussex, Reino Unido), fue una economista, periodista y escritora británicamás conocida por su interés y compromiso en los problemas de los países en desarrollo.
} 
La cultura U'wa practica la relevancia moral hacia los otros seres no humanos, no haciendo distinción entre ellos y los animales en cuanto a que están conformados por las mismas propiedades originales esto incluye a los elementos no bióticos del ecosistema. Todo ello lo logran a través de una ontología propia y de la práctica de sus rituales, que tienen un sentido en la organización social pero que se integra de manera compleja con los ciclos cósmicos, solares, terrestres y humanos.

La idea de la transformación es un principio ecológico que alimenta la ontología U’wa apoyada en los principios de funcionamiento de los ecosistemas que comprende tanto su visión del mundo integrada a la vida material y cotidiana de las personas, la cual, incluyen sus narraciones, sus leyes, sus rituales y todo lo que es sagrado.

El elemento axiológico que alimenta la ontología de los U’wa, es que ellos recibieron la naturaleza para administrarla con inteligencia y disfrutarla con reverencia sin sentirse al margen de ella, siendo parte de ella porque está contenida de secretos y poderes, de deidades presentes vestidas de piedra, montaña, árbol, río, amanecer, solo a la espera de que el hombre indígena esté ahí, sintiendo la vida, aportando vibraciones que ha adquirido en su larga tradición histórica (MEN, 2001). Es por ello que ellos insisten en mostrarse como los postes que sostienen el mundo:

El respeto a lo vivo y a lo no vivo, a lo conocido y a lo 'desconocido' hace parte de nuestra ley: Nuestra misión en el mundo es narrarla, cantarla y cumplirla para sostener el equilibrio del universo. Nuestra Ley U'wchita es uno de los postes que sostienen al mundo. Nuestra ley es tan antigua como la misma tierra, nuestra cultura se ha organizado siguiendo el modelo de la creación, por eso nuestra ley de la tierra y la tierra es una sola (Werjain Shita, 2002, p. 2).

\section{Pensamiento Relacional: Equilibrio y Continuidad de la Vida}


Se puede afirmar finalmente que la ontología U’wa es una ontología relacional de tipo celebrativo-simbólica, que establece una relación social de subjetividades entre humanos y nohumanos, con los cuales, busca la trasformación del mundo natural con el fin de mantener el equilibrio y la continuidad de la vida.

Para finalizar y regresar a nuestra preocupación inicial sobre la búsqueda de elementos que contribuyan con la sutura a la fractura entre cultura y naturaleza, que se encuentra enraizada en el pensamiento moderno, en esta investigación se sostiene que es necesario plantear nuevos retos para la educación, no solo para la educación formal sino en los diferentes espacios en los que las nuevas generaciones son recibidas y socializadas. Promover un cambio social donde el axioma de la relacionalidad del todo sea concebido como omnipresente entre los eventos del hombre, esto es fundamental en el entendimiento del funcionamiento de la vida. Sin esta comprensión el hombre siempre estará separado de su propia naturaleza y de la naturaleza misma. También, para superar la crisis ambiental la presente reflexión plantea la necesidad de desarrollar un pensamiento contrario al pensamiento depredatorio (el que usa y desecha) urge un pensamiento que permita la cabida a los no-humano en una categoría diferente a la de objeto, por ello el rescate a la discusión de otras rutas ontológicas como la animista, analogista y totemista, suponen una posibilidad de relación con los seres no-humanos, pero también una nueva relación con los seres humanos, puesto el concepto de humanidad se amplía: si se ha tenido como presupuesto por años que todos somos animales (preceptos del naturalismo evolucionismo) también, se podría aceptar el precepto de acuerdo al "perspectivismo que el fondo común de la humanidad y la animalidad no es, como para nosotros, la animalidad, sino la humanidad" (Viveiros de Castro, 2013, p. 36). 
Todo esto contribuiría a empezar a cerrar la brecha entre cultura y naturaleza, si nos permitiesemos virar en esa nueva forma de concebir la realidad, y asi entre una posición intermedia entre el hombre andino que a cada ser se le trata de una manera justa de acuerdo al lugar que ocupa en el orden cósmico y considerar que lo que nos une a todo lo humano y no humano es la humanidad, en ese punto intermedio se podría tejer un nuevo futuro. Los U’wa con sus tradiciones y su concepción de la naturaleza, son testigos de dichas posibilidades, antes que los conflictos, el despojo y deterioro del territorio y la violencia acaben por extinguir a las pocas comunidades que, como ésta, son ejemplos vivos de la posibilidad de un sistema cultura naturaleza que busca permanentemente el equilibrio. Sería ingenuo pensar que de la noche a la mañana el pensamiento cambie en el contexto de la dinámica impuesta por el sistema de mercado que cada vez es más avasalladora, sin embargo, la filosofía y la reflexión se deben permitir y posibilitar el cambio de comportamiento.

\section{Posibles Críticas}

Entre las posibles críticas al pensamiento relacional que se plantea en este ejercicio reflexivo se encuentran aquellas que surgirían desde la mirada del naturalismo moderno, que podrían alertar sobre los riesgos de pasar de un antropocentrismo a un ecocentrismo extremo, donde el ser humano se diluya en un sinfín de organismos, lo que tiene implicaciones éticas, morales y políticas. Ante estas diferentes interpretaciones de ecocentrismo estaría lo que sería la línea del biocentrismo que al igual que en el antropocentrismo plantea una línea extrema y otra moderada. La primera propone no utilizar nunca bajo ningún punto de vista a otros seres, dada su realización teleológica y el florecimiento de su physis (Leyton, 2009, p. 42). De esta postura surgen preguntas cuestionadoras o más bien caricaturescas, como las que plantea Leyton (2009), ¿me dejo 
devorar por las bacterias que me atacan, en virtud del respeto de su telos y su desarrollo?, ¿me alimento de un animal vivo o prefiero comer lechugas? Para esto Reichmann (2004, citado en Leyton 2008) propone: tratar moralmente a un ser vivo se basa en dos principios la no maleficencia y la beneficencia, es decir por lo menos no dañarlo, ni menoscabar sus posibilidades de vivir bien (vivir de acuerdo a su télos) y en la medida de lo posible ayudarlo a vivir bien. Esta postura nos conduce a un biocentrismo moderado donde se definen a todos los seres vivos como dignos de consideración moral y es capaz de operacionalizar la ética y de establecer una manera de resolver los problemas que conllevan el otorgar un peso valorativo a la vida de los seres e inclusive a los recursos minerales. Es decir, el biocentrismo moderado pretende minimizar el daño y la devastación que causamos. Se constituye en una respuesta a la crisis ecológica por cuanto se ubica en el medio entre la pregunta filosófica acerca de la instrumentalidad de la naturaleza, matizando entre un "sólo la humanidad" egoísta y ecológicamente autodestructiva, versus un "medio ambiente que sólo él" sea sujeto de moralidad y que inmoviliza al hombre como agente moral (Leyton, 2009, p. 44).

Lo anterior plantea más preguntas que conllevan a preocuparse por los que viven hoy y por los que vivirán mañana, incluyendo a los recursos minerales de hoy y del futuro, ¿será necesario entonces ampliar el círculo de consideración moral para tener en cuenta los intereses de nuevos sujetos morales? Entonces, ¿habrá que establecer derechos a la naturaleza? Esto plantea una tensión entre reconocer derechos a entidades naturales, como también a no desconocer la particularidad humana como especie. La discusión está en la mesa y el camino que se siga ha de tener la capacidad de abordar los posibles conflictos y críticas que serían bombardeadas desde la teoría ética y práctica ético-política (Leyton, 2008, p. 43). 


\section{Referencias Bibliográficas}

Asou'was, A. d. (2013). Diagnóstico Plan de Salvaguarda Pueblo U’wa. Recuperado el 12 de 10 de 2014, de http://siic.mininterior.gov.co/sites/default/files/p.s_uwa_boyaca_version_preliminar.pdf

Barceló, M. S. (2012). Esfinge Apuntes para un pensamiento diferente. Obtenido de Aborígenes australianos: https://www.revistaesfinge.com/culturas/culturas-del-mundo/item/791aborigenes-australianos

Berraondo, M. (2006). Pueblos indígenas y derechos humanos. Bilbao: Universidad de Deusto.

Burman, A. (2017). La ontología política del vivir bien. En J. M. Koen de Munter, \& M. C. ilustraciones de tapa e interiores, Ecología y reciprocidad: (con)vivir bien, desde contextos andinos (págs. 155-173). La Paz: Plural.

Cárcamo, H. (2005). Hermenéutica y Análisis Cualitativo. cinta moebio(23), 204-216. Obtenido de www.moebio.uchile.cl/23/carcamo.htm

CIDEMOS. (2016). CIDEMOS. Obtenido de Documental Indígenas U'wa Colombia| Guardianes de la Madre Tierra: https://www.youtube.com/watch?v=4yPkISU8k28

Corradini, L. (2006). La nación. Recuperado el 13 de 10 de 2018, de Philippe Descola: "Los hombres no son los reyes de la naturaleza": https://www.lanacion.com.ar/833801philippe-descola-los-hombres-no-son-los-reyes-de-la-naturaleza

De la Cadena, M. \&. (2015). Anthropology and STS; Generative Interfaces Multiple locations. Hau: Journal of Ethnographic Theory, 5(1), 437-475. doi:10.14318/hau5.1.020 
Descola, P. (2002). La antropología y la cuestión de la naturaleza, traducción de Diana Rosas Riaño. En G. \&. Palacio, Repensando la naturaleza: encuentros y desencuentros disciplinarios en torno a lo ambiental (págs. 155-175). Leticia: Universidad Nacional de Colombia-Sede Leticia, Instituto Amazónico de Investigaciones Imani, Instituto Colombiano de Antropología e Historia, colciencias.

Descola, P. (2011). Más allá de la naturaleza y la cultura. En L. Montenegro, Cultura y Naturaleza (págs. 75-96). Bogota: Jardín Botanico José Celestino Mutis.

Escobar, A. (2012). Cultura y diferencia: la ontología política del campo de Cultura y Desarrollo. Revista de investigacion en cultura y desarrollo, 7-16.

Escobar, A. (2015). Territorios de diferencia: la ontología política de los "derechos al territorio". Desenvolvimento e meio ambiente(35), 89-100.

Estermann, J. (2006). Filosofía Andina. La Paz: ISEAT.

Falchetti, A. (1997). La ofrenda y la semilla: Notas sobre el simbolismo del oro entre los U'wa. Boletín Museo del Oro(43), 3-37. Recuperado el 24 de 10 de 2018, de boletin del museo del oro: https://publicaciones.banrepcultural.org/index.php/bmo/article/view/6882/7122

Falchetti, A. M. (2003). La búsqueda del equilibrio, Los uwa y la defensa de su territorio sagrado en tiempos coloniales. Bogotá: Academia colombiana de historia. .

Falchetti, A. M. (2005). Los uwa y la percepción indìgena de la historia. Boletìn de Historia y antigûedades, XCII(828), 45-64. 
Foladori, G. \&. (2005). ¿Sustentabilidad? Desacuerdos sobre el desarrollo sustentable. Colección América Latina y el Nuevo Orden Mundial. México: H. Camara Diputados, UAZ, Miguel Angel Porrua Librero - editor.

González Varela, S. A. (2015). Antropología y el estudio de las ontologías a principios del siglo XXI: sus problemáticas y desafíos para el análisis de la cultura. Estudios sobre las Culturas Contemporáneas XXI(42), 39-64. Recuperado el 28 de 08 de 2018, de Estudios sobre las Culturas Contemporáneas: http://www.redalyc.org/articulo.oa?id=31642649003

González, O. S.-R. (2016). La apertura ontológica de la antropologia contemporanea. Revista de Dialectología y Tradiciones Populares, LXXI(1), 101-128. doi:10.3989/rdtp.2016.01.003

Holbraad, M. (2014). Tres provocaciones ontológicas. Ankulegi: gizarte antropologia aldizkaria = revista de antropología social(18), 127-139.

Latour, B. (2007). Nunca fuimos modernos. Ensayo de antropología simétrica. Buenos Aires: Siglo XXI Editores Argentina.

Leyton, F. (2008). Ética Medio Ambiental: una revisi ón de la Ética Antropocéntrica . Revista de Bioética y Derecho , 34-43. Obtenido de PUBLICACIÓN CUATRIMESTRAL DEL MSTER EN BIOÉTICA Y DERECHO: http://revistes.ub.edu/index.php/RBD/article/view/7805/9706

Leyton, F. (2009). Recuperado el 20 de mayo de 2015, de http://www.bioeticayderecho.ub.es

MEN. (2001). Cartilla U'wa. Bogota: MEN.

Mitrovic, M. (2013). Philippe Descola o la promesa de una Antropología de la naturaleza. Antrhopia(11), 100-103. 
Murra, J. (1975). El Control Vertical de un Máximo de Pisos Ecológicos en la Economía de las Sociedades Andinas. En J. Murra, Formaciones Económicas y Políticas del Mundo Andino (págs. 59 - 113). Lima- Perú: IEP ediciones.

Osborn. (1985). El vuelo de las tijeretas. Bogota: Fundación de Investigaciones Arqueológicas Nacionales, Banco de la República.

Osborn, A. (1995). Las cuatro estaciones. Recuperado el 10 de 11 de 2014, de Las cuatro estaciones: http://www.banrepcultural.org/blaavirtual/sociologia/osborne/inicio.htm

Parra, Y. (2013). YolandaAbyaYala. Obtenido de Kajkrasa Ruyina_Pensamiento del pueblo U'wa_Berito Cobaria 1: https://www.youtube.com/watch?v=1RelWowL6GI

Parra, Y. (2013). YolandaAbyaYala. Obtenido de Memoria y Resistencia. Pueblo U'wa. Daris Marìa Cristancho 1: https://www.youtube.com/watch?v=wZfSGR3Kq6U

Pineda, R. (2005). robertopinedacamacho.com. Recuperado el 27 de 11 de 2014, de EL LABERINTO DE LA IDENTIDAD: http://www.robertopinedacamacho.com/wpcontent/uploads/2013/06/Pineda-2005-El-laberinto-de-la-identidad.pdf

Restrepo, L. F. (2007). Tengo los pies en la cabeza, de Berichá, los u’wa y los retos de la cultura del reconocimiento. (1. (.-1. Cuadernos de Literatura, Ed.) Recuperado el 3 de 11 de 2014, de Tengo los pies en la cabeza: http://revistas.javeriana.edu.co/index.php/cualit/article/viewFile/6631/5281

Rochas Vivas, M. (2010). Antes El amanecer. Recuperado el 9 de 12 de 2014 , de Antes El amanecer, Antología de las literaturas indígenas de los Andes y la Sierra Nevada de Santa Marta: http://babel.banrepcultural.org/cdm/ref/collection/p17054coll8/id/9 
Ruiz Serna, D. \&. (2016). Los debates del giro ontológico en torno al naturalismo moderno. Revista de Estudios Sociales [en linea](55), 193-204. doi:DOI: http://dx.doi.org/10.7440/res55.2016.13

Sánchez-Criado, T. (2005). Reseña de "Antropología de la Naturaleza" de Philippe Descola. AIBR. Revista de Antropología Iberoamericana,(43), 1-4.

Silla, R. \&. (2016). Ontologías: usos, alcances y limitaciones del concepto en antropología. Avá Revista de Antropología(29), 7-25. Obtenido de http://www.redalyc.org/articulo.oa?id=169053775001

Vasco Uribe, L. G. (1995). Reseña. Recuperado el 5 de 10 de 2014, de Reseña: http://www.luguiva.net/resenas/detalle.aspx?id=20

Villareal, P. (2013). La cosmopolítica amerindia y el pensamiento teórico-político latinoamericano, una alternativa a los EstudiosCulturales y el multiculturalismo. Obtenido de X Jornadas de Sociología. Facultad de Ciencias Sociales, Universidad de Buenos Aires, Buenos Aires.: http://www.aacademica.org/000-038/146

Viveiros de Castro, E. (2004). Perspectival Anthropology and the Method of Controlled Equivocation in Tipití. Tipití Journal of the Society for the Anthropology of Lowland South America., 2(1), 2-23. Obtenido de http://digitalcommons.trinity.edu/tipiti

Viveiros de Castro, E. (2013). La mirada del jaguar : introducción al perspectivismo amerindio. Buenos Aires: Tinta Limón. Obtenido de tintalimon.com.ar/descargar.php?libro=9789872739089 
Werjain Shita, A. d. (2002). U'wa: visión y testamento. Polis Revista Latinoamericana(3), 1-6. Recuperado el 22 de Octubre de 2018, de https://journals.openedition.org/polis/7768 